\title{
Типовой воинский храм Русской императорской армии в период правления Императора Николая II
}

\author{
А.И.Макаров, МАРХИ, Москва
}

Строительство типовых военных храмов в Российской империи началось в начале XX века и продолжалось до 1917 года. Статья посвящена возведённым образцовым храмам на территории Российской империи в начале XX века. Рассмотрены как сохранившиеся, так и разрушенные образцовые храмы Русской императорской армии начала XX века. На примере Москвы, Санкт-Петербурга и других городов России, Белоруссии, Украины, Польши, Казахстана, Узбекистана и Турции. Рассмотрены причины, вызвавшие необходимость создания типового проекта для подразделений Русской армии.

Ключевые слова: военный храм, армия, полки, снос церквей в XX веке.

Typical Military Temple of the Russian Imperial Army during the Reign of Emperor Nicholas II

A.I.Makarov, MARCHI, Moscow

Construction of standard military temples in the Russian Empire began in the early XX century and continued until 1917. The article is devoted to the model temples erected on the territory of the Russian Empire at the beginning of the XX century. It considers both preserved and destroyed model churches of the Russian Imperial army at the beginning of the XX century on the examples in Moscow, Saint Petersburg, and other cities in Russia, Belarus, Ukraine, Poland, Kazakhstan, Uzbekistan, and Turkey. The reasons for creating a standard project for Russian army units are considered.

Keywords: military temple, army, regiments, demolition of churches in the 20th century.

С начала XVIII века до своего падения, Российская империя, если не считать коротких перерывов, находилась в состоянии войны. Это и Северная война, длившаяся более двадцати лет, неоднократные войны с Польшей, со Швецией, войны с Францией, Японией, длительные кампании по завоеванию Кавказа. B XIX веке русские войска постоянно присутствовали в Средней Азии, а напряжение на границе за Уралом и на Северном Кавказе заставляло держать в этих регионах довольно большой воинский контингент. Балканские страны - Сербия, Болгария, Румыния - с помощью России приобрели независимость и создали свою государственность, а народы Закавказья - Грузия и Армения, благодаря военному вмешательству Российской империи, по сути, избежали уничтожения.

До Первой мировой войны набор в императорскую армию, осуществлялся в основном за счёт рекрутов-славян, в то же время в те периоды, когда шли крупномасштабные боевые действия, призывались десятки тысяч ополченцев разных национальностей. Так, в 1812-1814 годы, например, татары, башкиры, мещеряки и калмыки выставили 24 полка конницы, общей численностью более десяти тысяч человек, а во время Крымской войны с Францией, Англией, Турцией и Сардинией в кампанию 1854-1855 годов на Кавказе из местных жителей сформировали 30-тысячную милицию [1, с. 15].

Надо отметить, что политика Империи отличалась веротерпимостью, и армейское начальство стремилось создать приемлемые условия для проведения религиозных обрядов: распорядок учебных занятий составлялся в зависимости от праздников и постов мусульманского, православного и других календарей, а присягу новобранцев-рядовых, как и офицеров после окончания юнкерских училищ, принимали духовные лица основных традиционных конфессий империи. Уместно вспомнить участие духовенства разных конфессий в принятии присяги в Московском Александровском военном училище при производстве в офицеры, в описанный в повести А. Куприна «Юнкера».

По данным за 1912 год из 1260159 нижних чинов 78\% составляли русские (великороссы, малороссы, белороссы), $8 \%$ - поляки, 1,5\% - немцы, 4\% - евреи, 3\% - татары и башкиры, $2 \%$ - народы Закавказья, $2 \%$ - латыши и эстонцы, $1 \%$ - народы Поволжья (чуваши, марийцы, удмурты).

В 1912 году состав Российской императорской армии был такой: пехота - 820610 человек, кавалерия - 200133 человека, инженерные войска - 52058 человек, управление учреждениями военного ведомства - 42272 человека; отдельный корпус жандармов - 13091 человек; корпус пограничной стражи 59271 человек; казачьи войска - 64373 человека [1, с. 16-17].

Российское военно-морское ведомство империи решало вопросы обороны и защиты внешних границ Империи, но в обязанности этой структуры, в частности, входило решение многих задачи внутреннего характера, направленных на поддержание духовно-нравственного состояния армии и флота. Надо отметить, что в этот (имперский) период армия являлась наиболее совершенным примером организационной деятельности для большинства структур государственного управления и хозяйства ${ }^{1}$.

${ }^{1}$ Так, военный министр Д.А. Милютин в 1871 году в письме одному из видных деятелей Государственного совета князю С.Н. Урусову писал: «Мы далеко ещё не вышли из того исторического периода, начатого Петром Великим, когда созданная им армия завоевала наше место в Европе и сделалась краеугольным камнем всего нашего государственного строя. И поныне русская армия, ограждая внешнее могущество государства, служит вместе с тем весьма многим общегосударственным гражданским целям, а военное управление, помимо войск, совмещает в себе и многие задачи управлением гражданского» [1, с. 17]. 
До вхождения на престол императора Павла I все соборы, храмы и часовни при воинских частях находились в ведении местных епархий, и только с первой половины XIX века армейские и флотские церкви постепенно стали переходить в подчинение Военного и Морского ведомств. Начало было положено совершенно справедливыми реформами императора Павла I, и в соответствии с его Указом от 9 апреля 1800 года все военные храмы были переданы обер-священнику армии и флота (в дальнейшем его именовали протопресвитером армии и флота) протоиерею П.Я. Озерецковскому.

Как известно, военной и административной столицей России был Санкт-Петербург, но первопрестольная Москва также именовалась столицей. Численность санкт-петербургского гарнизона составляла около 100000 военнослужащих, а в Москве дислоцировался гарнизон гораздо меньшей численности. Расквартированы войска были как в Петербурге, так и в окрестностях: в Царском селе, Стрельне, Петергофе, Гатчине, Павловске, Ораниенбауме и Кронштадте. Практически все воинские части принадлежали гвардии - элите императорских вооружённых сил, а старейшие гвардейские полки располагались в непосредственной близости от императорских резиденций. Казармы, здания офицерских собраний, манежей, госпиталей, различных бытовых служб занимали целые кварталы и с возведёнными полковыми соборами создавали величественные ансамбли, гармонично вписывающиеся в структуру города и украшающие зачастую однообразную фронтальную застройку столичных проспектов и площадей.

Так, к 1917 году в Санкт-Петербурге функционировало более двадцати полковых церквей. Одной из замечательных доминант города до сих пор является Троицкий собор лейбгвардии Измайловского полка (архитектор В.П. Стасов), синий купол которого, равно как и купол Исаакиевского собора, парил над городом и виден был за многие километры от него. Удачно замыкал перспективу Литейного проспекта изящный «Сергиевский всей артиллерии собор»- собор во имя преподобного Сергия Радонежского (архитектор Ф.И. Демерцов, снесён в 1934 году). На небольшой площади на Пантелеймоновской улице (ныне улица Пестеля) по проекту В.В. Стасова был возведён Спасо-Преображенский всей гвардии собор, а напротив Царскосельского вокзала по проекту К. Тона и на средства императора Николая I отстроен собор Введения Пресвятой Богородицы лейбгвардии Семёновского полка (снесён в 1936 году). Ксенинскую площадь украсил замыкающий анфиладу полковых построек Благовещенский собор лейб-гвардии Конного полка архитектора К. Тона (снесён в 1932 году), по его же проекту для прославленного лейб-гвардии Егерского полка, в котором начинали службу генералиссимус А.В. Суворов и П.И. Багратион на Обводном канале был построен храм святого Мирона (снесён в 1932 году).

На Захарьевской улице органично вписался в городскую застройку собор лейб-гвардии Кавалергардского полка (разрушен в 1952 году), а в Новом Петергофе, лейб-уланы Её Величества получили компактный собор Святых Апостолов Петра и Павла (архитектор К. Тон, собор снесён в 1930-е годы). До 1917 года в воинских храмах Российской империи находились ещё и исторические музеи, и эта необходимая традиция пополнения экспозиции свято соблюдалась. Храмы хранили бесценные свидетельства славных подвигов солдат и офицеров ${ }^{2}$.

В императорской России существовала традиция, которая сейчас возобновляется: внутренние и внешние стены армейских храмов украшать мемориальными досками с именами погибших. Если раньше на них поимённо выбивались фамилии только генералов, адмиралов и офицеров, то в настоящее время указываются имена нижних чинов Российской армии и Российского флота.

На протяжении конца XVIII - начала XX века воинские храмы отличались от обычных приходских только вместимостью и по сути являлись также и приходскими. Как при епархиальных, так и при воинских храмах организовывались церковно-приходские школы, приюты для детей-сирот, общества помощи бедным, различные учебно-воспитательные учреждения, что способствовало морально-нравственному воспитанию населения.

Хотелось бы отметить, что часто даже в столицах - Петербурге и Москве, не говоря уже о губернских городах, дислоцированные на их территориях воинские подразделения использовали для церковных служб помещения полковых казарм, их пристройки, временные церкви в лазаретах, приделы епархиальных церквей, что было неудобно как для военнослужащих, так и для местных жителейз. Сложная ситуация сложилась в губерниях Привислянского края (Польша), где была высокая концентрация войск, так как западное направление рассматривалось как наиболее вероятный район возникновения театра военных действий.

Военный министр Алексей Николаевич Куропаткин совершенно справедливо считал одним из главных направлений в сфере государственной политики в отношении армии поддержку православной веры, которой придерживалось подавляющее большинство военнослужащих, и при нём в начале $X X$ века при Главном штабе была создана Особая комиссия по вопросам «удовлетворения религиозных нужд войск». В 1900 году им на имя императора Николая II был составлен доклад «по

${ }^{2}$ В Спасо-Преображенском всей гвардии соборе, например, хранились полковые знамёна и трофеи: 488 знамён, 3 знака, 16 флагов, 10 бунчуков, 1 булава, 12 жезлов, 12 замков и 65 ключей от взятых неприятельских крепостей и городов. В этом же храме, шефом которого по традиции являлся император, хранились мундиры августейших особ. В ризнице этого собора находилось напрестольное Евангелие, украшенное 2628 бриллиантами [1, с. 22].

${ }^{3}$ Так, полковая церковь во имя святого первомученика и архидиакона Стефана 8-го драгунского Астраханского полка, дислоцировавшегося в Тирасполе, арендовала для церковных служб помещение жилого дома мещанина Чапелыги, а военнослужащие 42-го Сибирского полка использовали домовую церковь томского местного лазарета (источник: https://ru.wikipedia.org/wiki). 
улучшению быта низших чинов», в котором отмечалось, что «в настоящее время представляется необходимым изыскать средства для постройки церквей при всех частях, которым по штату положены священники и для расширения существующих войсковых храмов, для чего необходимо разработать тип военной церкви, хотя бы барачной системы, но вместительной и недорогой, чтобы изысканием для постройки церквей средств не пришлось откладывать этой насущной нужды».

На этом документе рукой императора начертано: «Дай Бог, в скором времени удовлетворить религиозные нужды войск, что Я считаю делом в высшей степени важным. 23 января 1900 года» [2, с. 13].

В соответствии с высочайшим повелением комиссию возглавил член Военного совета генерал от инфантерии граф Татищев при участии протопресвитера морского духовенства, а также представителей Главного штаба и Главного инженерного управления. Основной целью работы комиссии было решение вопросов удовлетворения религиозных нужд войск и поднятие их религиозно-нравственного воспитания. Комиссия, закончив обсуждение этих вопросов, предложила особый тип военной церкви, достаточно удобной по вместимости, строгой и скромной по архитектуре и экономичной при строительстве. Были разработаны храмы на 400, 600 и 900 человек, несколько разнившиеся по размеру, но общие по архитектонике, стоимостью 40 000-44 000 рублей.

Уместно отметить, что одновременно с военным ведомством морское ведомство разработало проект флотской морской церкви.

«1-го декабря 1901 года состоялось Высочайшее повеление. 1) "установить на будущее время к исполнению правило, чтобы в казармах Военного Ведомства, как существующих, так и возводимых вновь распоряжением и на средства этого ведомства, православная церковь, в виде отдельного здания, была непременной принадлежностью казарм тех частей войск, по штатам коих положены церковные причты..." (Приказ по Воен. Вед. 23 января 1902 г. за № 32)».

При этом приказом по Военному ведомству от 23 января 1902 года № 20 командованию на местах предписывалось: «...руководствоваться при постройке войсковых церквей Высочайше одобренным проектом таковой церкви».

Впервые в истории Российской империи типовой проект воинского храма был реализован при строительстве в 1901-1903 годах в Новом Петергофе церкви 148-го пехотного Каспийского полка во имя святой великомученицы Анастасии Узорешительницы.

Новая каменная церковь была торжественно заложена 30 июня 1901 года в присутствии императора Николая II, а спустя два года, 5 июня 1903 года новопостроенный храм был освящён в его присутствии. Закладку и освящение осуществил протопресвитер военного духовенства Александр Желобовский. Проект был разработан военным инженером Фёдором Михайловичем Вержбицким ${ }^{4}$ (рис. 1 a).

Автор весьма удачно решил поставленную перед ним задачу: однонефная, несколько удлинённая базилика в плане была корректно сочленена с трёхчастным объёмно-простран-

\footnotetext{
4 Ф.М. Вержбицкий - полковник-инженер. Специалист по железнодорожному и казарменному строительству. Работал в Виленской губернии (1871-1882), в Полтаве (1882-1886), Чернигове (1886-1890). Преподаватель Школы десятников (1900-е), член правления Общества гражданских инженеров. Надворный советник.
}

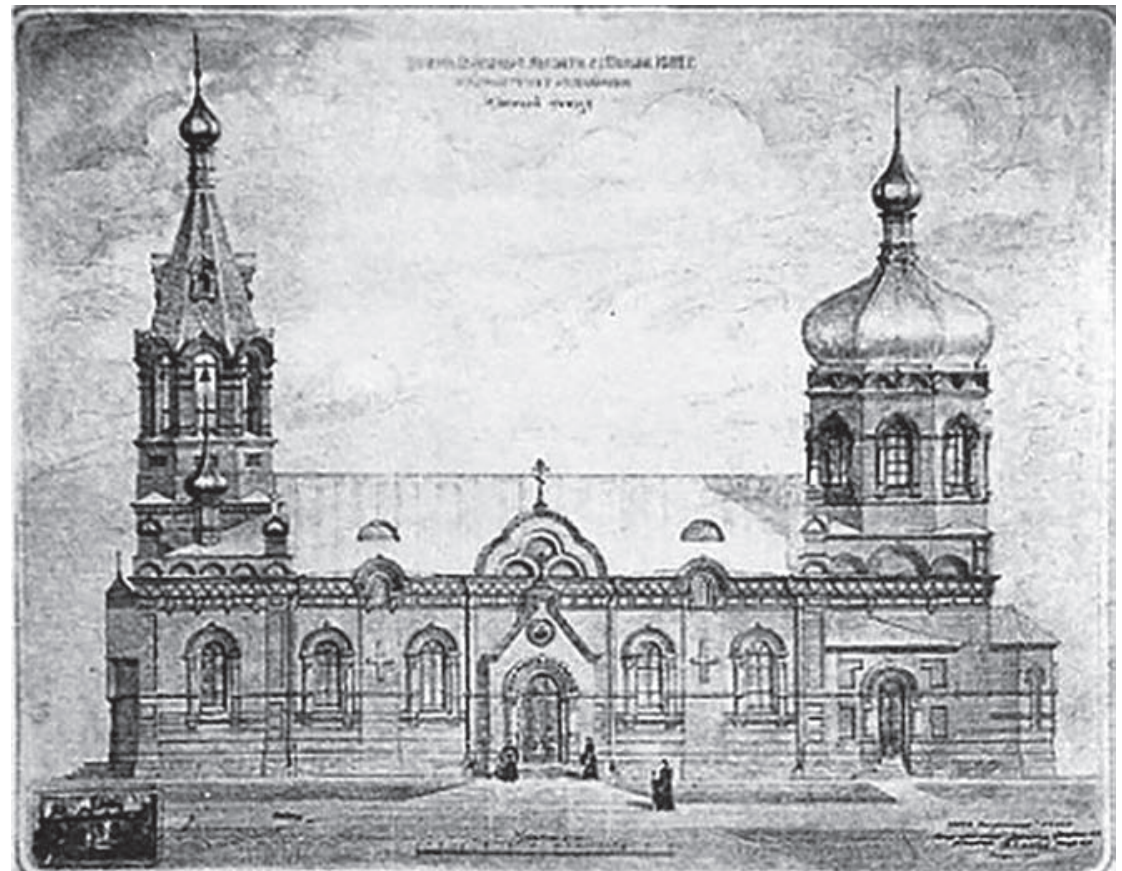

a)

Рис. 1. Храм во имя святой великомученицы Анастасии Узорешительницы 148-го пехотного Каспийского полка. Новый

Петергоф: а) чертёж; б) общий вид (фото из открытых источников сети Интернет)

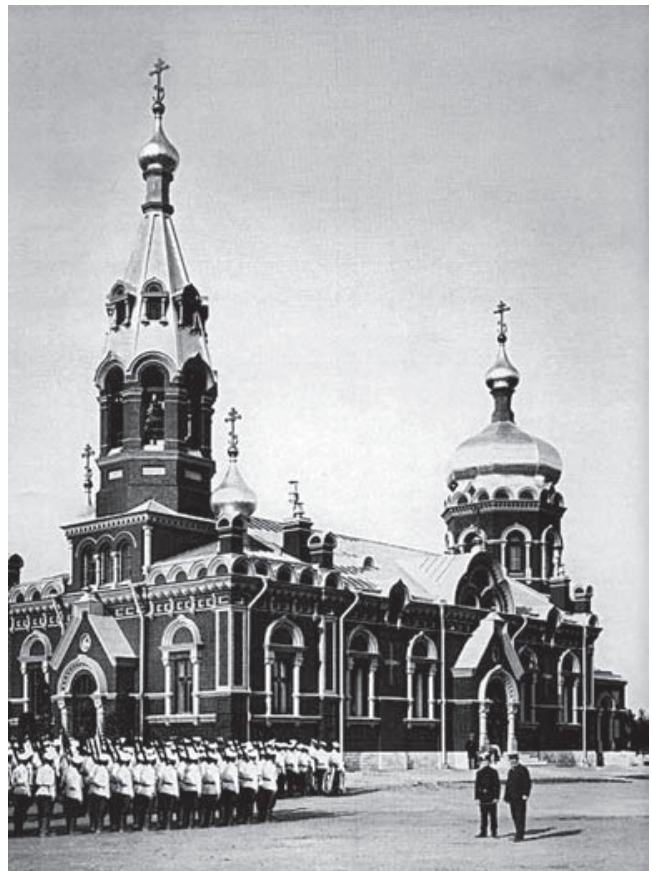

\section{6)}


ственным делением, которое было свойственно для распространённого типа русских церквей: шатровая колокольня над западным входом, затем трапезная и основной объём храма (восьмерик на четверике) со световым барабаном (восьмериком) над восточной частью храма.

Судя по сохранившимся в настоящее время типовым воинским церквям, основное помещение здания было перекрыто большепролётными металлическими фермами из уголков на болтовых соединениях, к которым был подвешен оштукатуренный потолок в форме коробового свода из дерева. Восьмерик алтаря и яруса звона колокольни в соответствии с проектом должны были также иметь деревянные подвесные потолки - над ярусом звона он должен быть плоским, а в алтарной части восьмерика должен был иметь форму восьмигранного сомкнутого свода. С учётом того, что строительство должно было быть недорогим, конструкции главы и шатра в соответствии с образцовым проектом предполагалось выполнять из дерева.

Рядом с первым типовым храмом в 1911 году была сооружена часовня, в которой был погребён прах бывшего командира Каспийского полка генерал-лейтенанта барона Фёдора Фёдоровича Таубе (разрушена в 1930-е годы).

Появление этого храма современниками было воспринято весьма позитивно. Сам тип его продолжал направление в церковном зодчестве, начатое великим российским архитектором К. Тоном, который сумел удачно сочетать существующие традиции национального храмостроительства с новыми технологиями в области строительного дела: с использованием минимальных средств достигать наибольшей выразительности (рис. 1 б).

Перед освящением готового храма газеты писали: «Церковь в русском стиле отличается изящной простотой архитектуры, каменная, одноэтажная, выложенная красным кирпичом, увенчанная большим куполом над алтарём. Над западным фасадом высится 15 сажень (32 метра) колокольня, звон которой составляет 9 колоколов, самый большой - 168 пудов (2750 кг), 9 железных золочёных крестов украшают алтарную часть крыши. Пол её из разноцветных метлахских плит. Красивый иконостас из резного светлого дуба, вмещает 13 образов. Как они, так и 4 изображения евангелистов внутри купола и стенная живопись по потолку, исполнена масляными красками Обществом Вспомоществования недостаточным Русским Художникам. С середины церкви спускается большое бронзовое паникадило, престол храма сооружён в честь святой великомученицы Анастасии, память которой празднуется 5 июня, день тезоименитства Августейшей малютки-дочери Их Величеств» [3, с. 240]. Как мы видим, реализация проекта, утверждённого лично императором удалась, и автор был награждён премией в 500 рублей.

В настоящее время сильно обезображенное здание храма сохранилось, однако каких-либо мер по его восстановлению в Санкт-Петербурге не предвидится (рис. 2).

К концу XIX - началу XX века русские архитекторы постепенно (ещё до типового проекта Вержбицкого) пришли к выводу, что армейский храм должен быть вместимостью в 600-1200 человек, иметь продолговатую форму с одним или тремя приделами. И такие храмы появились: в 1897 году в Кутаиси был освящён храм в честь святого благоверного князя Александра Невского 1-го Хопёрского полка, который по архитектуре являлся в какой-то степени предтечей храмов, построенных по типовому проекту. В 1904 году освящена возведённая по проекту архитекторов-академиков Д. Зайцева и А. фон Гогена и при участии военного инженера капитана Никифорова церковь Хрисанфа и Дарии при лейб-гвардии Драгунском полку в Высочайшем присутствии протопресвитером военного и морского духовенства А. Желобовским в сослужении протоиерея И. Кронштадского (рис. 3). В крепости Грозный в начале прошлого века появилась большая двухпридельная церковь святителя Николая Чудотворца 82-го пехотного Дагестанского полка, возведённая по проекту гражданского инженера Чернявского.

По проекту известного зодчего А.Г. Успенского в СанктПетербурге был возведён храм святого архистратига Михаила лейб-гвардии Московского полка, а в Бобруйске (Варшавский

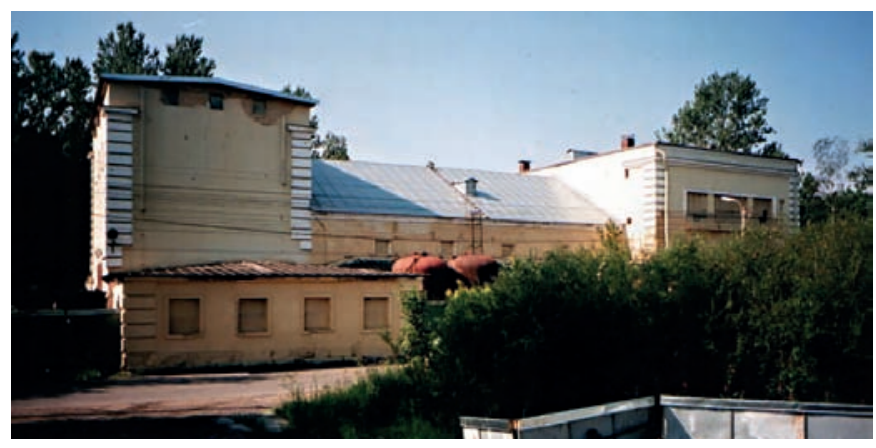

Рис. 2. Храм во имя святой великомученицы Анастасии Узорешительницы. Петергоф. Современное состояние (фото из открытых источников сети Интернет)

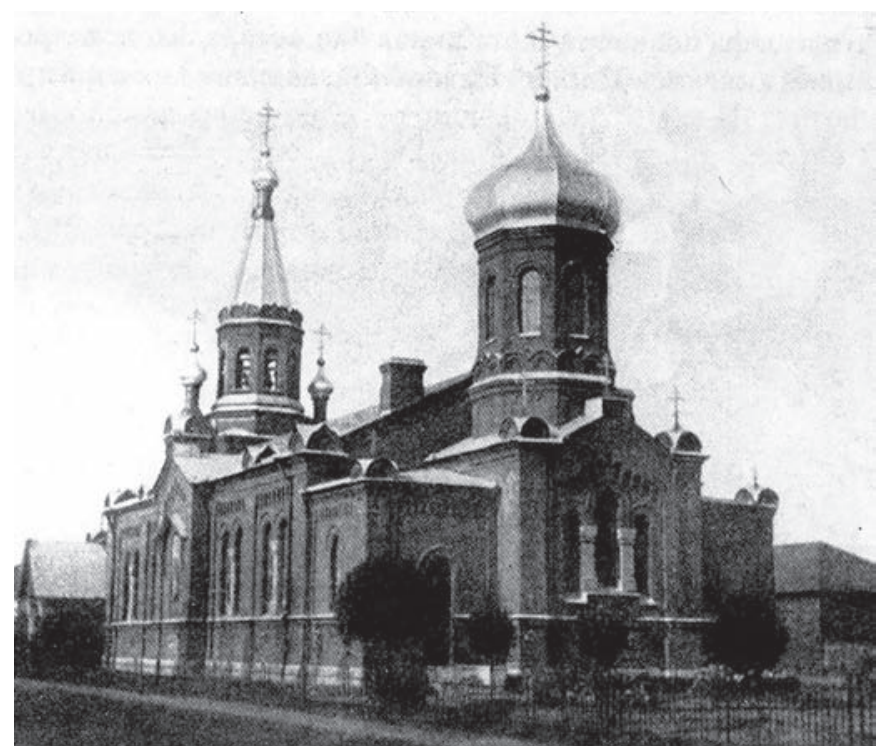

Рис. 3. Церковь Хрисанфа и Дарии при лейб-гвардии Драгунском полку. 1904 год (фото из открытых источников сети Интернет) 
военный округ, сейчас территория Республики Беларусь) по проекту архитектора В. Чагина построен храм святителя Николая 152-го Кутаисского пехотного полка. Судя по внешнему облику этих храмов, автор, по всей видимости, ориентировался на проекты, утверждённые императором.

Реализация этого типового проекта стимулировала строительство воинских храмов на территории всей империи. По данным исследователей, до 1917 года было построено 69 типовых храмов.

Как уже отмечалось, значительное количество таких типовых храмов возводилось на территории Варшавского военного округа. Так, в 1902-1904 годах в Варшавском районе Мокотово, на территории военного городка лейб-гвардии Кексгольмского пехотного полка, появилась церковь святых Петра и Павла (рис. 4). Хотелось бы отметить, что в Польше, начиная с 20-х годов прошлого века, русофобия, являвшаяся как и в другие исторические периоды, одним из направлений государственной политики, приняла весьма уродливые формы, которые подразумевали жёсткую борьбу с православием.

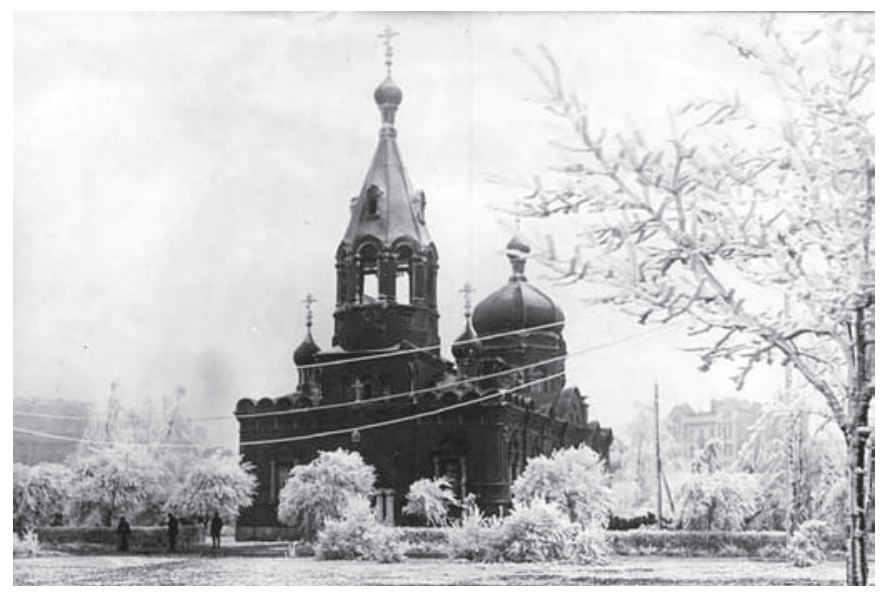

Рис. 4. Церковь Петра и Павла при Кексгольмском лейбгвардии полку. Варшава (фото из открытых источников сети Интернет)

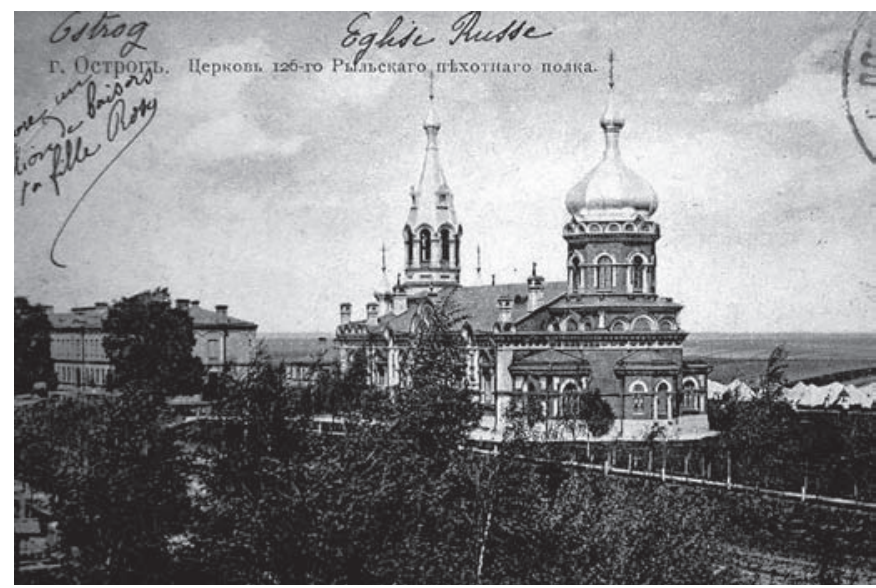

Рис. 5. Церковь Георгия Победоносца при 126-ом пехотном Рыльском полку. Город Острог Волынской губернии (фото из открытых источников сети Интернет)
Упомянутый храм, например, после ликвидации православной общины в начале прошлого века был передан лютеранской церкви. В городе Остроге Волынской губернии (в начале XX века - Польша, сейчас Ровенская область Украины) в 1906 году была сооружена полковая церковь 126-го Рыльского пехотного полка в честь священномученика святого Георгия Победоносца, уничтоженная в 20-х годах прошлого века, так как оказалась на оккупированной Польшей территории (рис. 5).

Город Белосток был единственным в империи населённым пунктом, где по типовому проекту были сооружены два храма: первый - храм Успения Пресвятой Богородицы при 64-ом Казанском пехотном полку, был освящён в ноябре 1904 года (рис. 6), а до этого момента, подразделение использовало походную Успенскую церковь. Второй типовой храм - церковь св. Захарии и Елизаветы 4-го уланского Харьковского полка, был освящён в 1911 году.

Белостокский Успенский храм, как и следовало ожидать, при сохранённом общем архитектурном объёме был обезглавлен, лишён основной главы, декоративных элементов, свидетельствующих о принадлежности к православной церкви, и превращён поляками в гарнизонный костёл.

В 1907 году в небольшом городке Грубешев (Варшавский военный округ, Польша) была освящена церковь св.

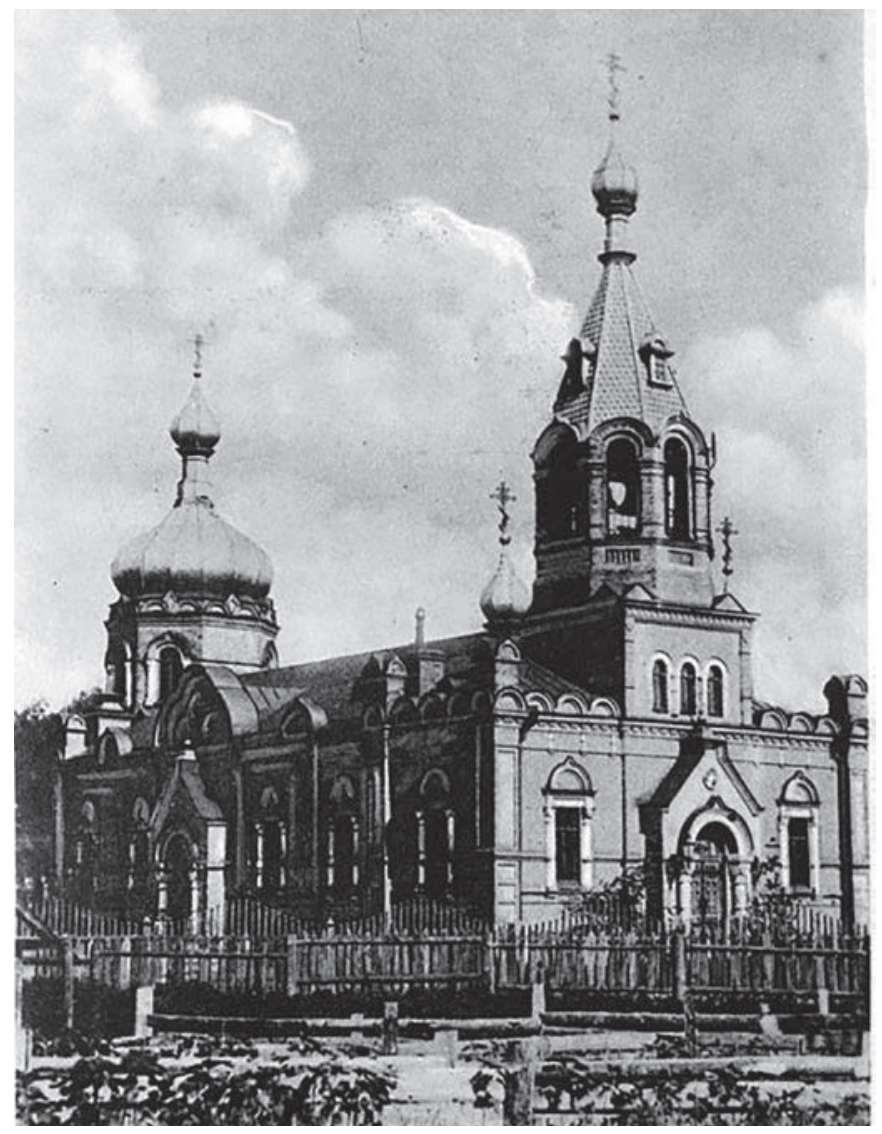

Рис. 6. Церковь Успения Пресвятой Богородицы при 64-ом Казанском пехотном полку. Белосток (фото из открытых источников сети Интернет) 
Николая Чудотворца 7-го уланского Ольвиопольского полка, построенная также по типовому проекту. Её также постигла печальная участь: в 20-е годы прошлого века она была обезглавлена и переоборудована в католический костёл, а в годы Второй мировой войны здание использовалось немецкой армией под конюшню и склады (рис. 7). В настоящее время в нём снова католический храм. Не избежала подобной участи и церковь Грузинской иконы Божией Матери при 69-ом Рязанском пехотном полку в городе Люблине (рис. 8). Эта однокупольная православная воинская церковь,

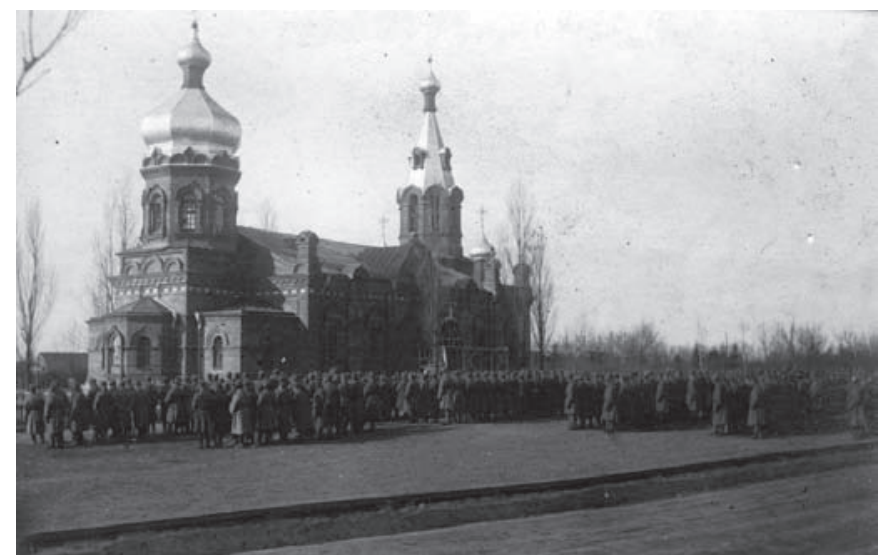

Рис. 7. Церковь св. Николая Чудотворца 7-го уланского Ольвиопольского полка (фото из открытых источников сети Интернет)

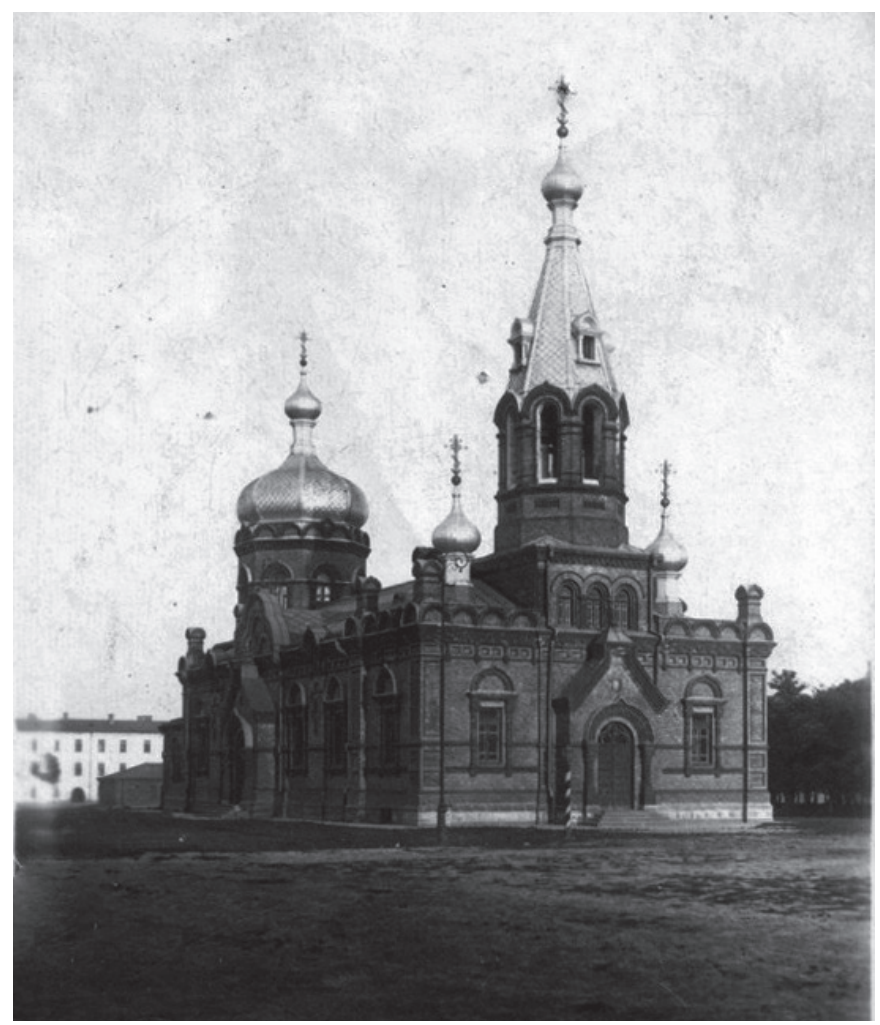

Рис. 8. Церковь Грузинской иконы Божией Матери при 69-ом Рязанском пехотном полку. Люблин (фото из открытых источников сети Интернет) построенная в форме базилики, также в 1929 году была захвачена католической церковью Польши, несмотря на то, что в этом населённом пункте, равно как и в Белостокском воеводстве, православных верующих было достаточно много - белорусов, русин. В городке Новоалександрия (Варшавский военный округ, сейчас польский город Пулавы) церковь Троицы Живоначальной при 71-ом Белёвском пехотном полку, возведённая в 1909 году, лишилась всех архитектурных православных элементов и после реконструкции была передана католическому приходу (рис. 9).

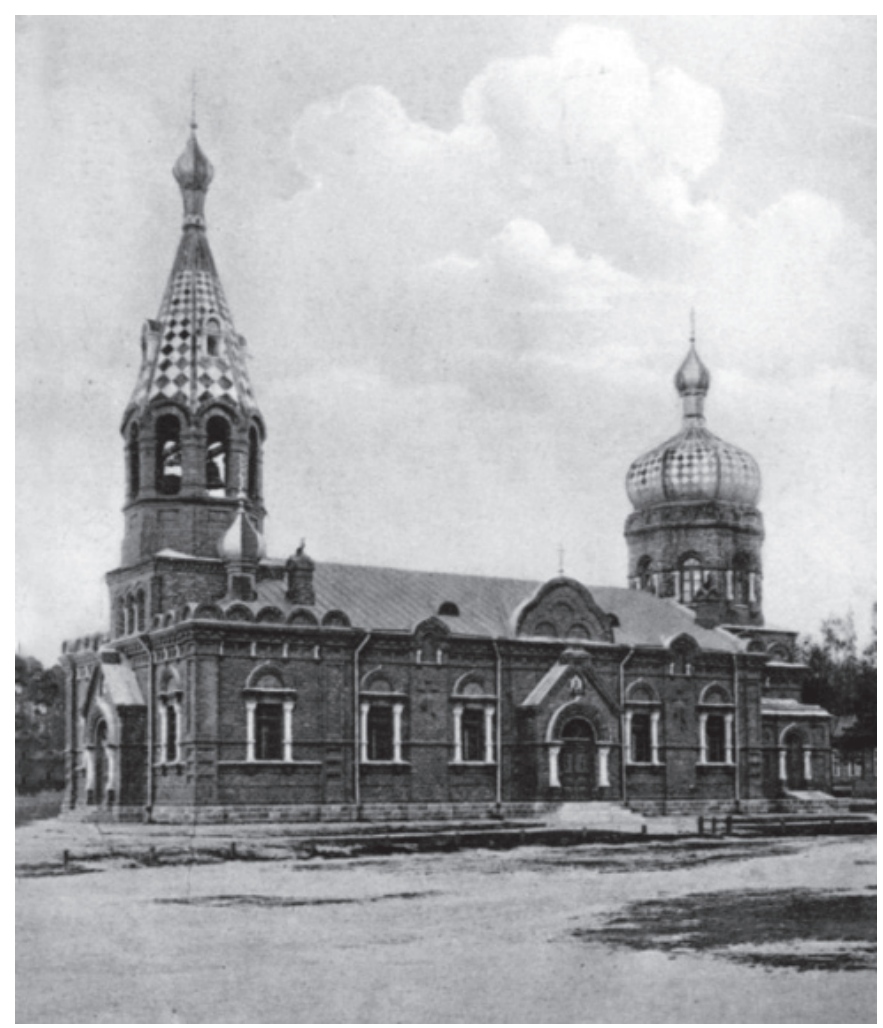

Рис. 9. Церковь Троицы Живоначальной при 71-ом Белёвском пехотном полку. Пулавы, Польша (фото из открытых источников сети Интернет)

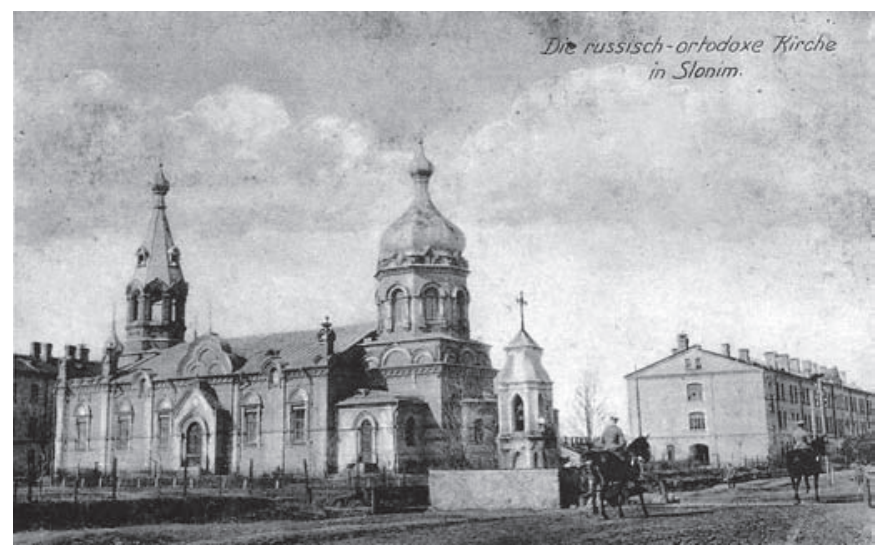

Рис. 10. Церковь 118-го Шуйского пехотного полка в честь св. благоверного князя Александра Невского (фото из открытых источников сети Интернет) 


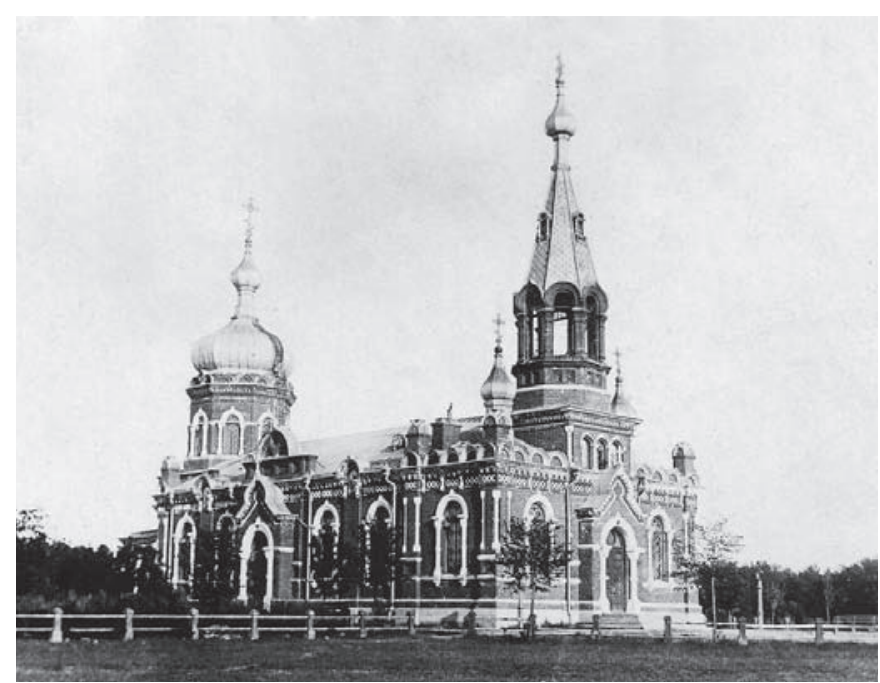

Рис. 11. Церковь Покрова Пресвятой Богородицы 113-го пехотного Старорусского полка. Лиепая, Латвия (фото из открытых источников сети Интернет)

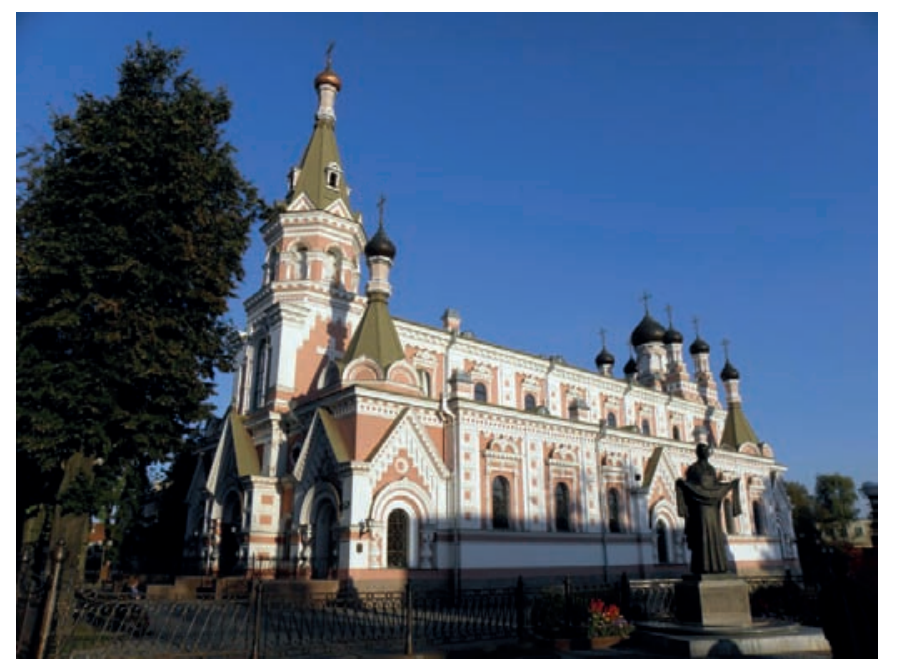

a)

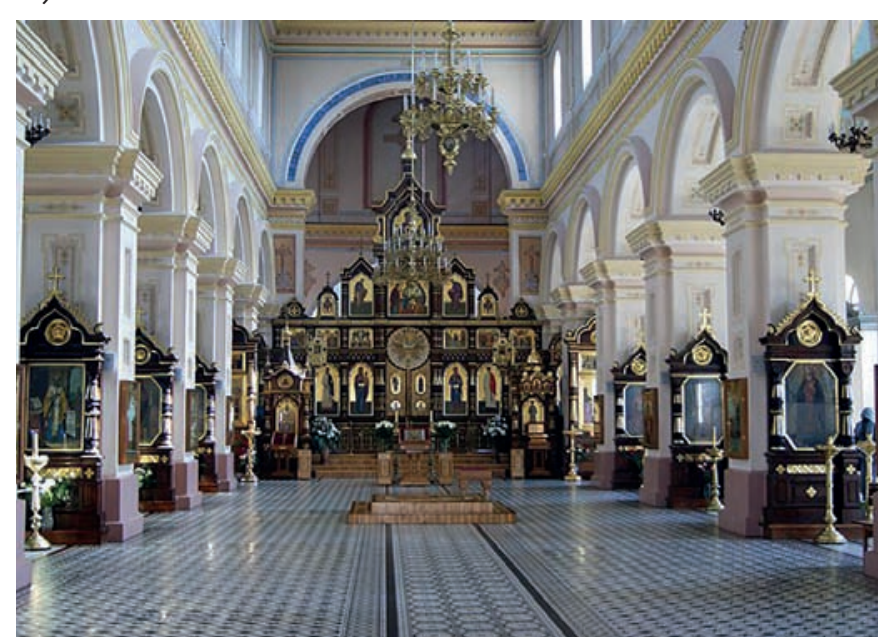

б)

Рис. 12. Кафедральный собор Покрова Пресвятой Богородицы. Гродно, Белоруссия. Фото А.И. Макарова. 1998 год: а) внешний вид; б) интерьер
В небольшом уездном городе Слоним Гродненской губернии в 1909 году также появилась вмещавшая 900 человек церковь 118-го Шуйского пехотного полка в честь святого благоверного князя Александра Невского, пришедшая на смену походной, существующей с 1863 года и сопровождавшей полк в Русско-японской войне в 1904-1905 годов. Как и большинство церквей, она располагалась в центре гарнизонной застройки (рис. 10). Здание сохранилось и функционирует как католический костёл.

В 1905 году при штабе Либавской крепости (в настоящее время - латвийский город Лиепая) в порту Императора Александра III был освящён типовой храм Покрова Пресвятой Богородицы 113-го пехотного Старорусского полка (рис. 11), позднее, в 1923 году разобранный на кирпич для достройки латышской лютеранской церкви (Лиепая, ул. Ялгавс, 60). А на месте разрушенного храма сейчас пустырь и заросли кустарника.

0 том, что типовой проект был удачным, свидетельствует такой факт, что в память о погибших в Русско-японской войне 1904-1905 годов воинах Гродненского гарнизона по проекту архитектора М.М. Позарова в 1907 году был возведён СвятоПокровский гарнизонный храм. За основу проекта был взят Петергофский храм Каспийского полка. Активную роль в разработке проекта сыграл военный инженер Инженерного управления Варшавского военного округа И.И. Савельев. В храме в соответствии в российской воинской традицией были установлены мемориальные доски с имена погибших. В конце декабря 1993 года эта традиция была продолжена, и стенах Покровского собора были размещены памятные доски с имена воинов-интернационалистов, погибших в Афганистане (рис. 12).

Строительство типовых воинских храмов охватило всю империю. Так, на Дальнем Востоке на острове Русском была к 1917 году выстроена Свято-Георгиевская церковь 36-го ВосточноСибирского стрелкового полка (рис. 13). В Приморье по проекту

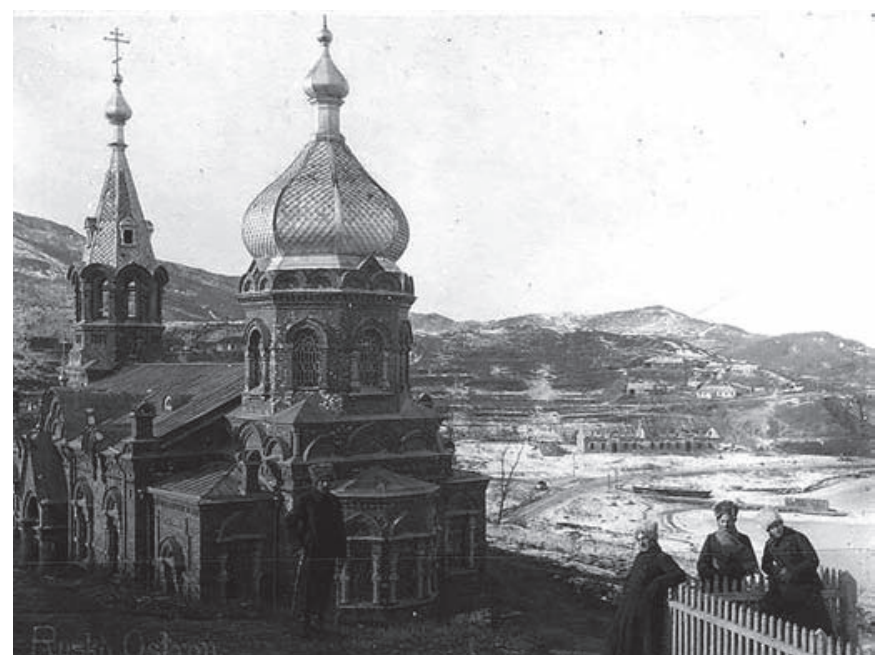

Рис. 13. Церковь Георгия Победоносца при 36-м Сибирском стрелковом полку (фото из открытых источников сети Интернет) 
В. Вержбицкого были возведены полковые церкви в селе Раздольное Рождественского района, на Дальнем Востоке в городе Спасске и в крепости Чныррах. Эти церкви не сохранились. Даже в таком отдалённом месте, как населённый пункт Усть-Кяхта (Бурятия) за короткий срок была возведена церковь во имя Михаила Архангела для 20-го Сибирского стрелкового полка. В 2014 году церковь при попустительстве военного командования гарнизона, на территории которого она находилась, была разобрана на кирпич для коммерческого строительства (рис. 14).

В 1906 году центральную улицу города Барнаула (Томская губерния) украсила построенная менее чем за два года Никольская церковь Барнаульского стрелкового полка, в возведении которой участвовали как воины местного гарнизона, так и местные жители. Длительное время храм не функционировал, а в настоящее время активные реставрационные работы позволили вернуть ему первоначальный облик. По старым фотографиям был воссоздан вызолоченный иконостас, а иконы были выполнены палехскими иконописцами.

В 1913 году в восточной части города Новониколаевска (сейчас город Новосибирск) на средства казны (37 000 рублей) в военном городке, где размещались 41-ый Сибирский полк, 22-ая Сибирская артиллерийская бригада и 1-ый Сибирский дивизион, был возведён храм Николая Чудотворца, рассчитанный на 600 человек, колокольня которого стала композиционным центром для окружающих армейских строений. В советское время там располагались армейские учреждения культуры.

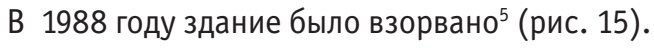

В 1927 году был закрыт, а в 1960-х годах прошлого века разрушен типовой воинский храм Покрова Пресвятой Богородицы при 44-ом Сибирском пехотном полку, сооружённый в Омске в 1909 году.

Проект, утверждённый императором, был основным для строящихся храмов Туркестанского военного округа. Так, в соответствии с ним был возведён храм святого благоверного князя Александра Невского 1-ой Туркестанской стрелковой бригады, квартировавшейся в Ташкенте, а в 1912 году в самом городе Самарканде был освящён собор святителя Алексия Московского, причём в архитектуру храма инженером Ф. Смирновым были внесены незначительные изменения (рис. 16).

Ранее, в 1907 году в городе Фергана для 7-го Туркестанского стрелкового полка на средства Военного министерства был возведён храм Николая Чудотворца (рис. 17), а в городе Термезе для воинского контингента 9-го Туркестанского стрелкового полка, Термезской крепостной стрелковой роты и Туркестанской понтонной роты была возведена из светлосерого жжёного кирпича и в 1905 году освящена церковь Алексия, человека Божия.

${ }^{5}$ Священником храма был Николай Звездин, который во времена Русскояпонской войны находился в Сибирском пехотном полку. Императорским указом он был награждён орденами Святой Анны 2 и 3 степеней за то, что совершая «пасторские обязанности, под выстрелами неприятеля, помогал раненным; на перевязочном пункте поддерживал дух и веру отряда» (источник: https://ru.wikipedia.org/wiki).

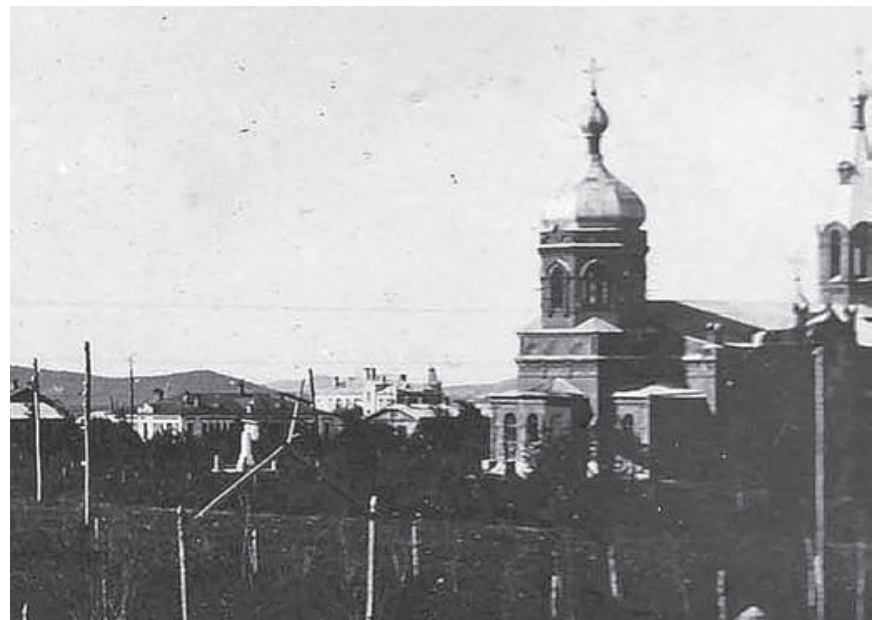

Рис. 14. Церковь Михаила Архангела при 20-ом Сибирском стрелковом полку (фото из открытых источников сети Интернет)

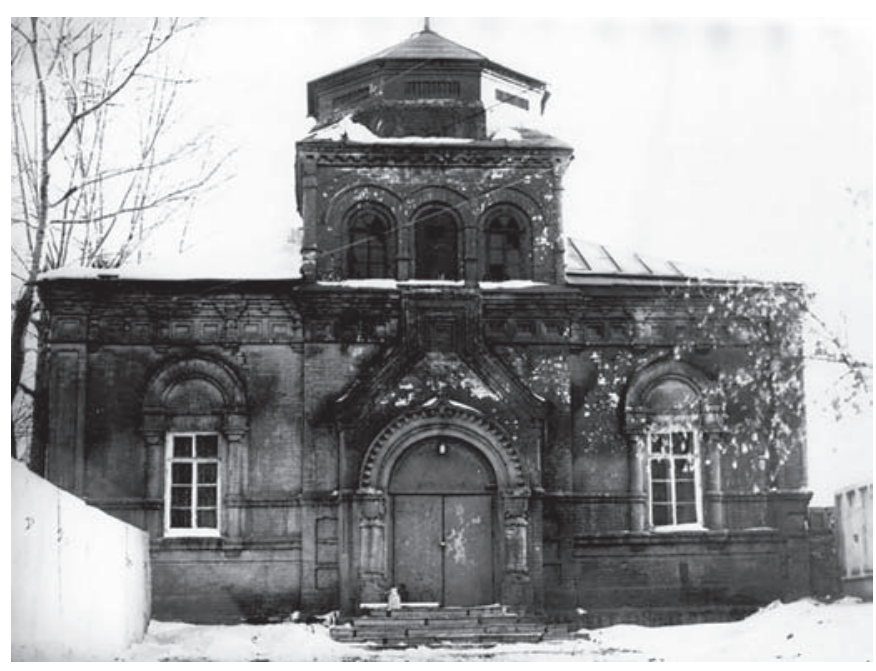

Рис. 15. Церковь Николая Чудотворца 41-го Сибирского стрелкового полка. Новосибирск (фото из открытых источников сети Интернет)

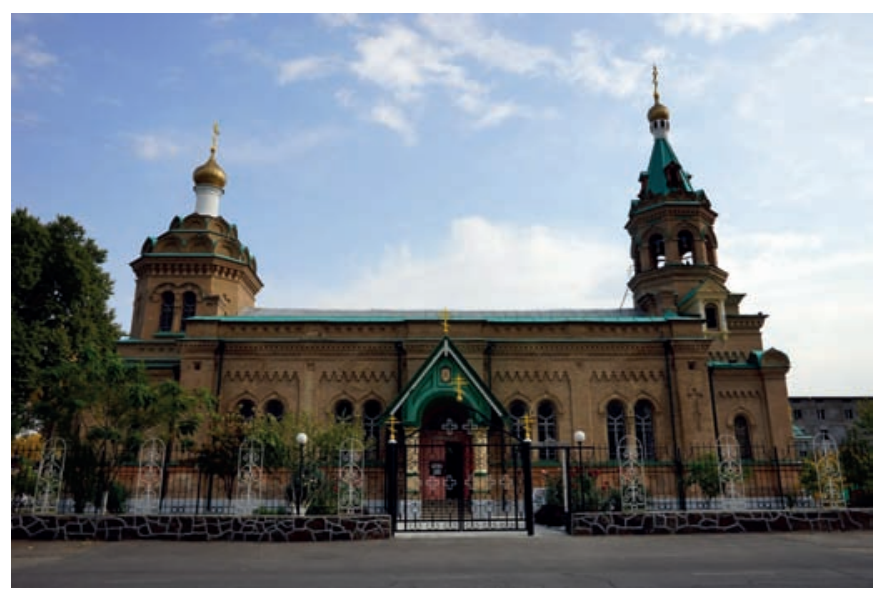

Рис. 16. Собор свт. Алексия митрополита Московского. Самарканд, узбекистан (фото из открытых источников сети Интернет) 


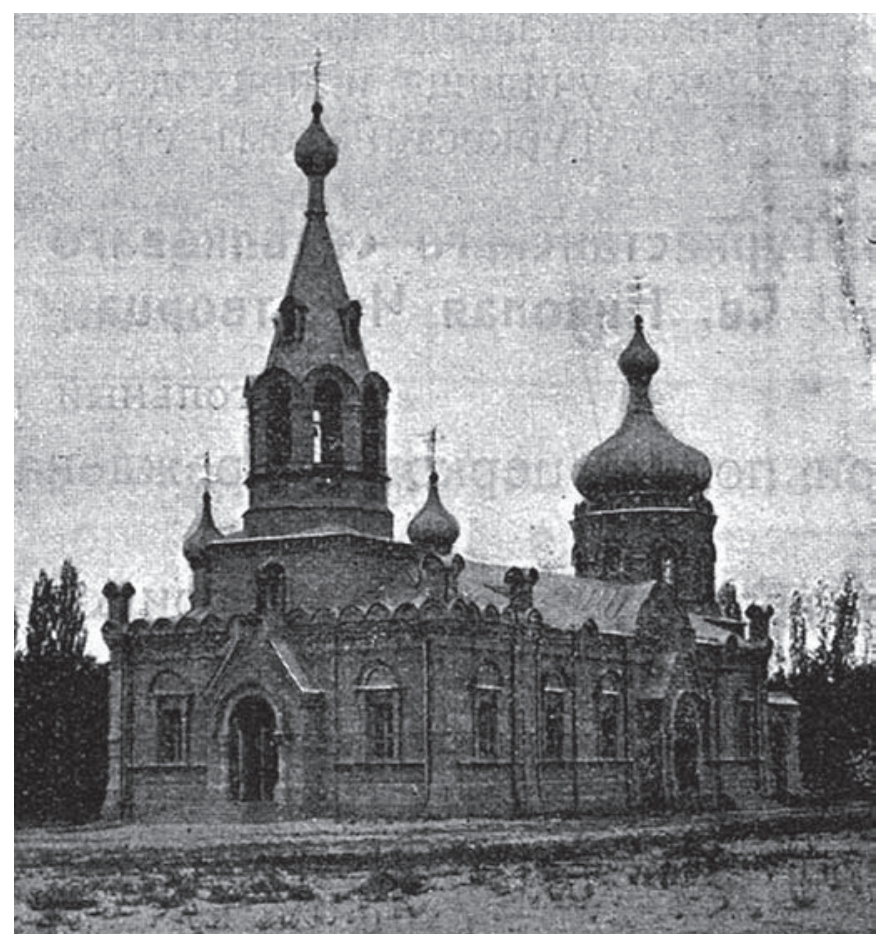

Рис. 17. Церковь Николая Чудотворца при 7-ом Туркестанском стрелковом полку. Фергана, Узбекистан (фото из открытых источников сети Интернет)

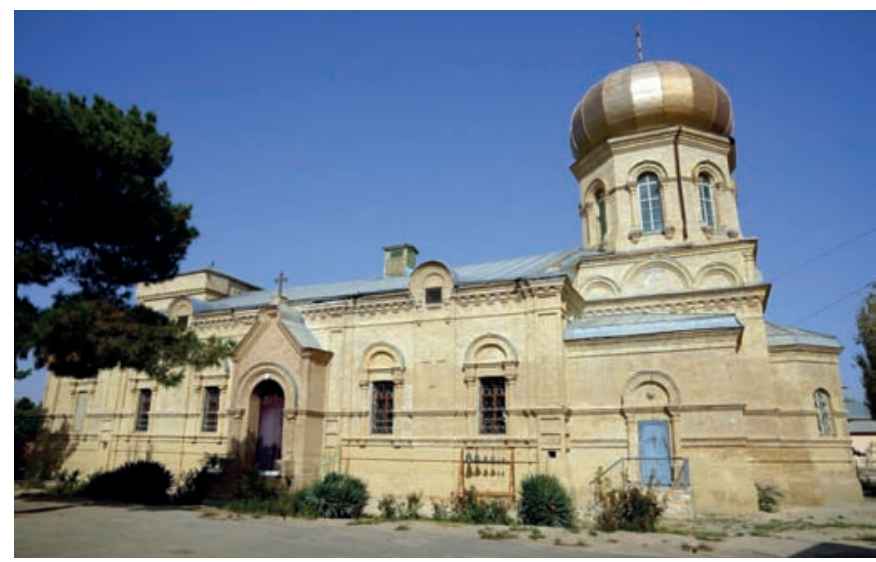

Pис. 18. Церковь святого благоверного Александра Невского. Термез, Узбекистан (фото из открытых источников сети Интернет)

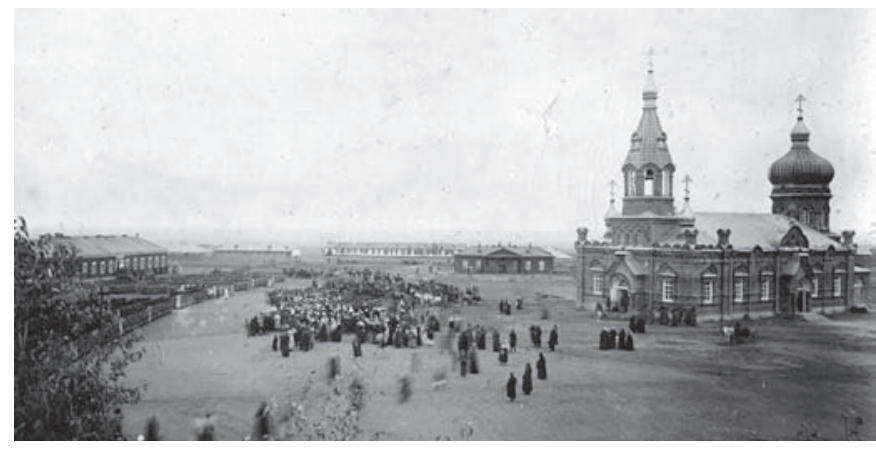

Рис. 19. Собор Николая Чудотворца. Зайсан, Казахстан (фото из открытых источников сети Интернет)
Благодаря тому, что с 1927 года в здании находился спортзал, церковь сохранилась и в 1990 году была вновь освящена, но уже в честь святого благоверного князя Александра Невского (рис. 18).

В одной из самых отдалённых точек Туркестанского военного округа - в городе Кушка (сейчас Серхетабад, Туркмения), также на средства, полученные от казны, в 1908 году в условиях тяжелейшего климата сооружена и освящена церковь Николая Чудотворца при 15-ом Туркестанском стрелковом полку.

В небольшом городе Зайсане (Восточный Казахстан) по предложению военного министра А.Н. Куропаткина на средства военного министерства был возведён войсковой храм святителя Николая Чудотворца, первоначальный облик которого в XX веке был искажён значительными перестройками (рис. 19).

Как на территории западных губерний Российской империи, так и в восточных её районах приходилось держать крупные воинские подразделения, которые также нуждались в постоянном духовном окормлении. Например, в бывших владениях империи на территориях, отошедших к Турции, построено много воинских типовых храмов, чему способствовало наличие легко обрабатываемых местных строительных материалов.

В 1908 году в крепости Карс для 154-го Дербентского полка и Уманского казачьего полка был построен из черно-зелёного туфа храм, освящённый в честь святого благоверного князя Александра Невского ${ }^{6}$ (рис. 20). И, как было принято, на стенах располагались 12 мраморных плит с именами воинов, погибших в 1830-1872 годах. Как и на других территориях, отринутых от России, впоследствии здание лишилось православной атрибутики, к нему пристроен минарет, и оно используется в настоящее время как мечеть Фетхие-Джами.

${ }^{6}$ В храме (в качестве вклада) находилось икона пророка Елисея в серебряном окладе, весом около 30 кг, пожалованная шефом полка А.И. Барякинским, восемь икон, пожертвованных в 1774 году графом Ф. Апраксиным, Евангелие 1735 года, а также мундир шефа полка Александра III.

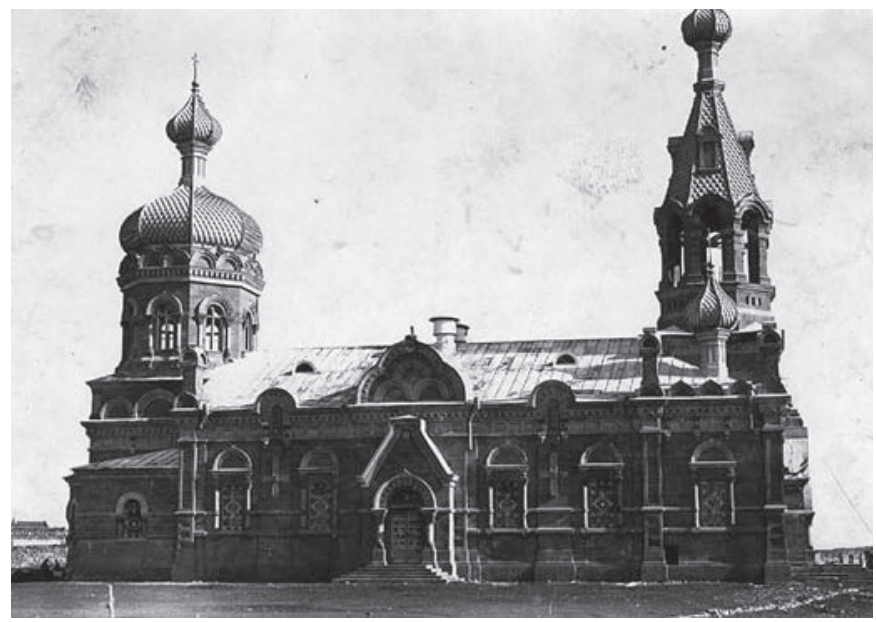

Рис. 20. Церковь Александра Невского при 154-м пехотном Дербентском полку. Крепость Карс (фото из открытых источников сети Интернет) 
Если для постройки типовых воинских храмов в центральном, сибирском, дальневосточном и западном регионах использовался, как правило, кирпич, то в южных районах, как мы видим, удачно применялись местные строительные материалы. Так, церковь святого благоверного князя Александра Невского при 1-ом Горно-Моздокском полку, возведённая в 1909 году в городе Ольты (в настоящее время Олты, провинция Эрзерум, Турция), получила уникальную облицовку наружных стен туфом разных оттенков - песочного и тёмно-серого (рис. 21).

С 1922 года, после отхода города Артвин к Турции, на его территории оказался построенный из местного светлого туфа войсковой храм апостолов Петра и Павла при 1-ом Кубанском Пластунском батальоне, который не сохранился (рис. 22).

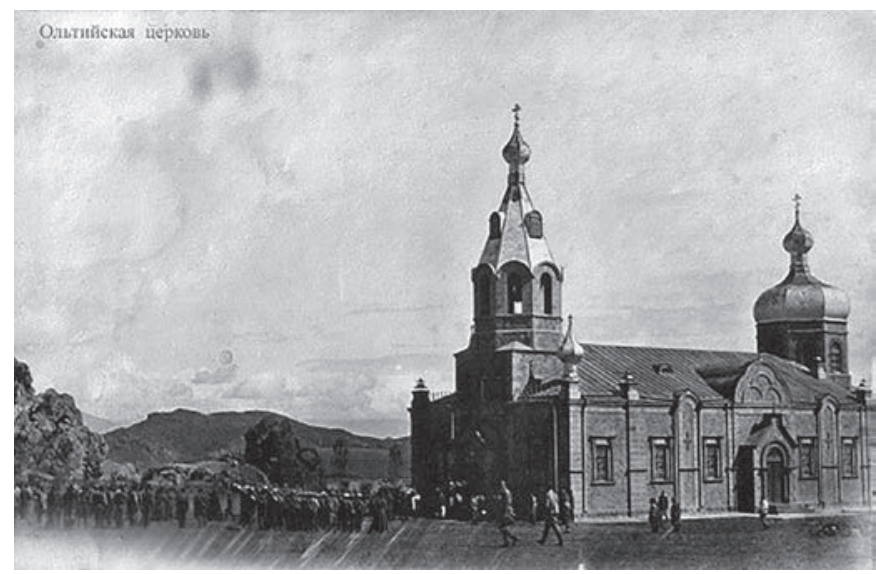

Рис. 21. Церковь Александра Невского при 1-ом Горско-Моздокском полку. Олту (Ольты), Турция (фото из открытых источников сети Интернет)

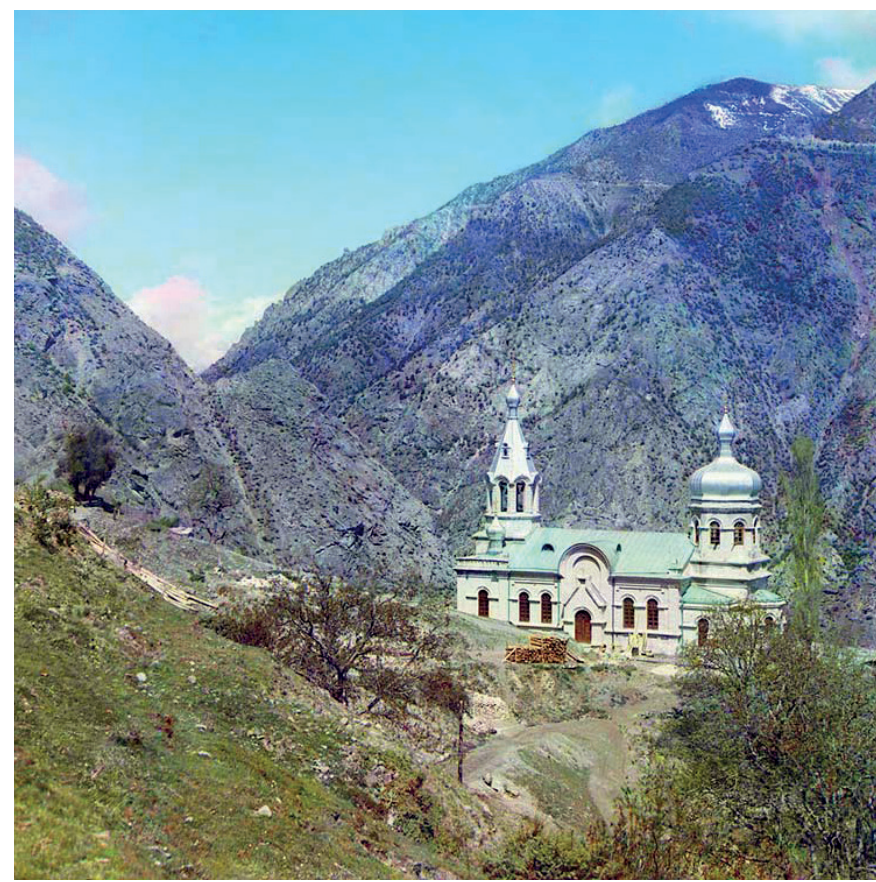

Рис. 22. Церковь апостолов Петра и Павла при 1-м Кубанском пластунском батальоне. Артвин, Турция (фото из открытых источников сети Интернет)
Не пощадила судьба и церковь Михаила Архангела 156-го Елисаветпольского пехотного полка в городе Сарыкамыши, героически сражавшегося во время русско-турецкой войны 1877-1878 годов и отмеченного георгиевскими знамёнами: «За взятие Ардогана, 4 и 5 мая» и «За сражение на Аладжинских высотах 3 октября 1877 года», а также отличившегося в Первой мировой войне на турецком фронте при разгроме турок под Эрзерумом. Храм, оказавшийся на территории Турции был впоследствии разрушен (рис. 23).

На территории малороссийских губерний в местах расположения воинских частей в начале прошлого века также возводились стационарные воинские церкви по типовым проектам. В 1910 году на окраине села Белокриница Кременецкого района

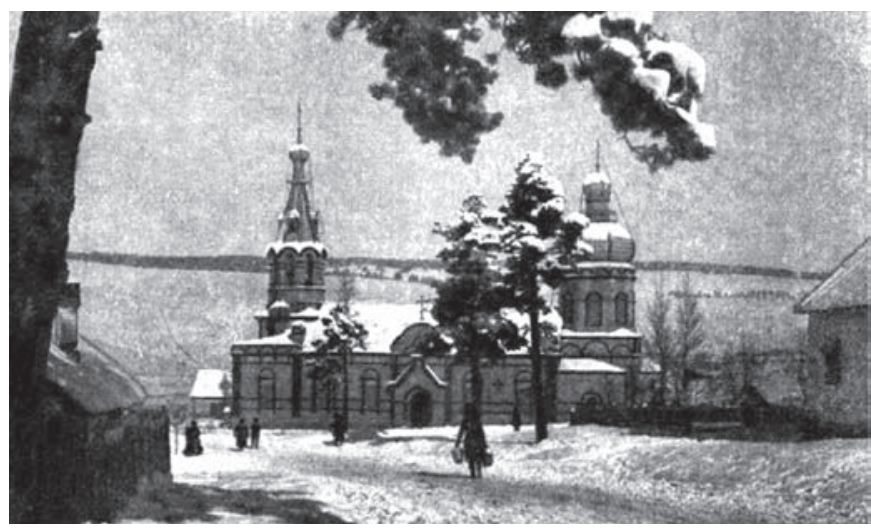

Рис. 23. Церковь Михаила Архангела при 156-ом пехотном Елисаветпольском полку. Сарыкамыш, Турция (фото из открытых источников сети Интернет)

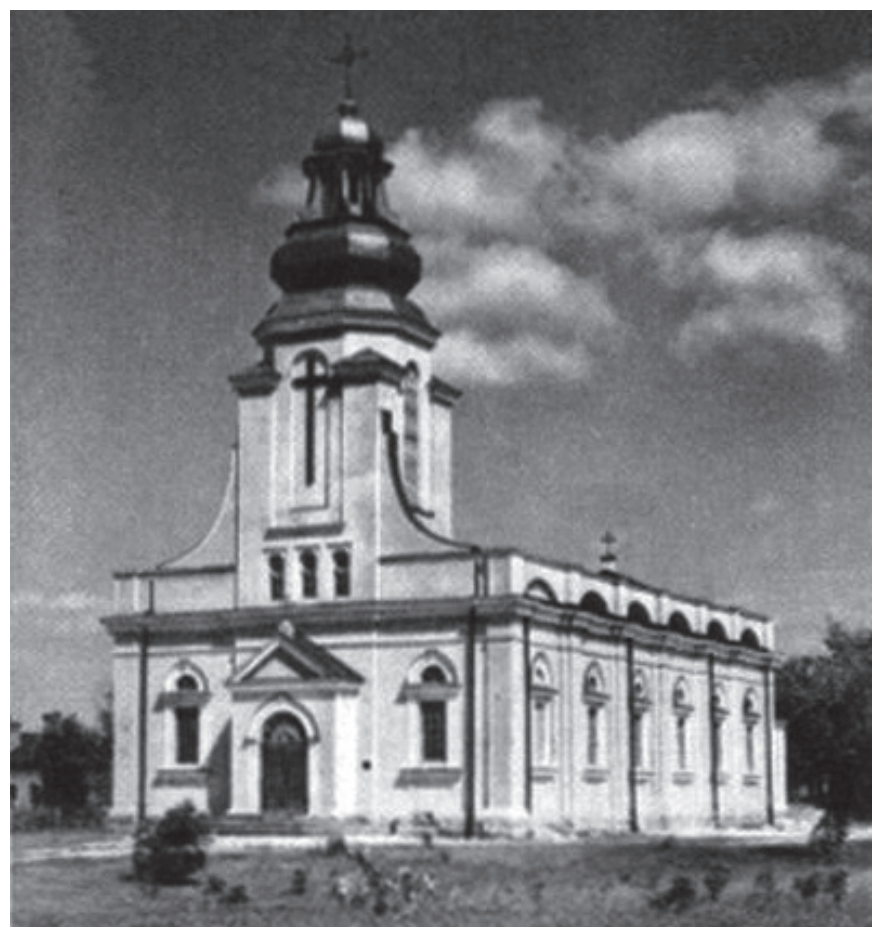

Рис. 24. Церковь Покрова Пресвятой Богородицы 11-го Драгунского Рижского полка. Белокриница, Украина (фото из открытых источников сети Интернет) 
Волынской губернии появился храм Покрова Пресвятой Богородицы 11-го драгунского Рижского полка, который в период нахождения на оккупированной Польшей территории (1921-1939), был обезглавлен и превращён в католический собор. Несмотря

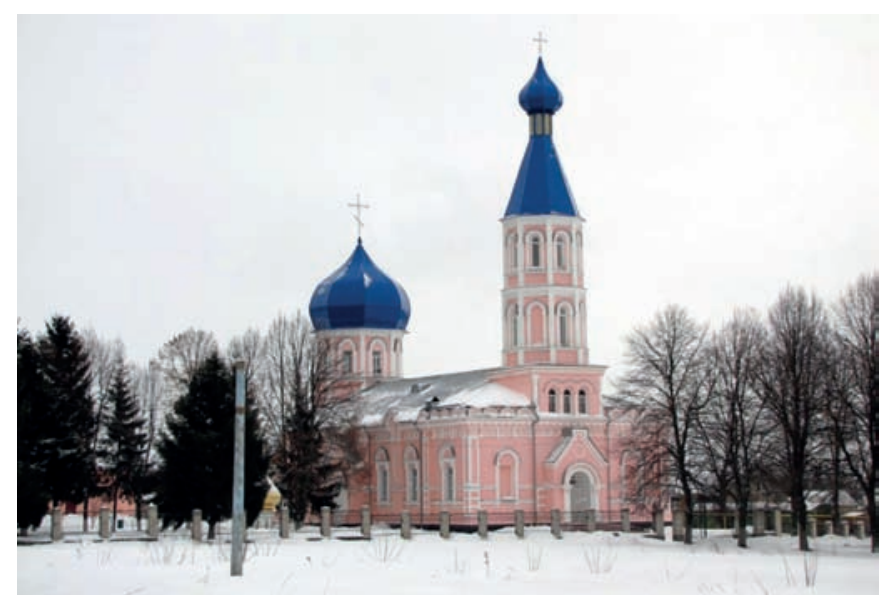

Рис. 25. Церковь Николая Чудотворца 9-го и 10-го стрелковых полков. Жмеринка, Украина (фото из открытых источников сети Интернет)

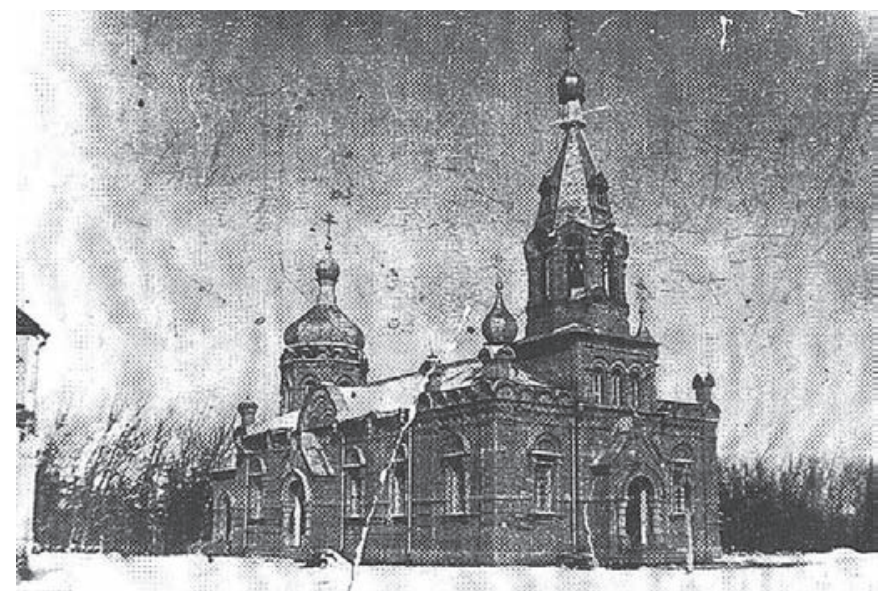

Рис. 26. Церковь Вознесения Господня при 45-м пехотном Азовском полку. Староконстантинов, Украина (фото из открытых источников сети Интернет)

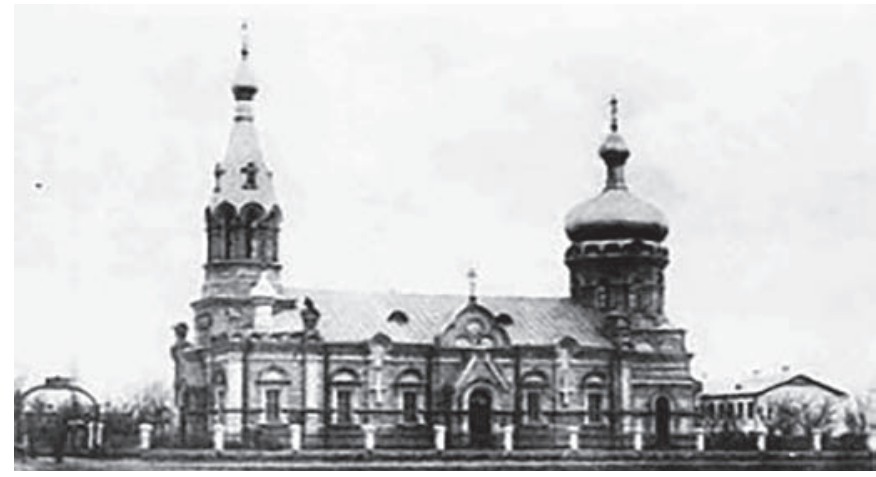

Рис. 27. Церковь Троицы Живоначальной при 56-м Житомирском пехотном полку. Тирасполь, Бессарабия (сейчас - Приднестровская Молдавская Республика) (фото из открытых источников сети Интернет) на то, что основной объём здания был сохранён, архитектурный облик был обезображен громоздкой колокольней, не соответствующей первоначальному облику здания (рис. 24).

В городе Жмеринка (Украина) в настоящее время функционирует церковь Святителя Николая, возведённая для чинов 9-го и 10-го стрелковых полков 3-ей стрелковой бригады. Это здание можно привести в качестве неудачного примера реконструкции, так как колокольня, воссозданная на месте разрушенной в 1930-е годы, очевидно диссонирует с первоначальным обликом здания (рис. 25).

На территории города Балаклея (Харьковская область, бывший город Александрополь) частично сохранившийся воинский храма святого Митрофания Воронежского 5-го кавалерийского полка (освящён в 1911 году), расположенный на территории Балаклейского ремонтного завода, медленно разрушается из-за отсутствия средств на его восстановление. В годы борьбы с религией в городе Днепропетровске (бывший Екатеринославль) был закрыт и обезглавлен освящённый в 1912 году типовой храм 133-го Симферопольского пехотного полка, и в настоящее время то, что от него осталось, представляет неприглядное зрелище - апсида отсутствует, а к остальным фасадам в советское время пристроены служебные здания Приднепровской академии строительства и архитектуры.

В то же время на Украине существуют удачные примеры использования зданий воинских храмов, построенных в имперское время. Так, в 1995 году в безвозмездное пользование Украинской православной церкви Московского Патриархата была передана церковь святого Георгия Победоносца 135-го пехотного Керчь-Енапольского полка в Павлограде, которая была заново освящена в честь Покрова Пресвятой Богородицы.

45-ый пехотный Азовский полк, находясь на протяжении 35 лет в месте постоянной дислокации в городе Староконстантинове (Хмельницкая область, Украина), не имел своей церкви и пользовался с конца XVIII века походной, которая сопровождала его в Турецкие войны (1827-1829, 1877-1881), а также во время Крымской войны в Севастополе (1854-1855). В 1909 году на средства казны полк получил типовой храм, который был впоследствии разрушен (рис. 26).

В столице Приднестровской Молдавской Республики Тирасполе хорошо сохранился построенный за один год полковой храм Троицы Живоначальной 56-го Житомирского пехотного полка, вмещавший 1000 человек. Он был освящён в 1904 году. До освящения этот полк также располагал походной церковью, которая использовалась при походах подразделения во время Великой Отечественной войны 1812 года, в турецкую войну (1827-1829), в 1849 при усмирении Трансильвании, при обороне Севастополя (1854-1855), в Русско-японской войне (1904-1905) (рис. 27).

В городе Алма-Ата (совр. Алматы, Республика Казахстан) на казарменной площади (бывшей Красной) на территории войскового плаца и зданий казарм Семиреченского казачьего конного полка на месте существующего Дома правительства Казахской 
ССР (архитектор М.Я. Гинзбург, 1931) находилась освящённая в 1906 году войсковая церковь во имя святителя Алексия Митрополита Московского 20-го Туркестанского стрелкового полка. С большой вероятностью можно предположить, что храм мог быть освящён в день рождения цесаревича Алексия (5 октября 1906) - шефа всех казачьих войск Императорской армии. Судя по сохранившимся фотографиям, здание этого храма несколько отличалось от типового проекта отделкой фасада, в которой использовались элементы неорусского деревянного стиля окон, входных дверей и карнизов, а пилястры завершались символическими элементами воинской атрибутики, таким же образом были обыграны козырьки над входами в храм. Здание было возведено архитектором Семиреченской областной инженерной дистанции С. Тропаревским и инженером Я. Порошенным (рис. 28).

В данной ситуации следует отметить, что за возведением воинских храмов, как правило, наблюдал местный архитектор или инженер-строитель, который, не внося каких-либо существенных изменений в проект Вержбицкого, в ряде случаев изменял форму главы, крыльца, обрамления кокошников на фасадах и др. Так, в Санкт-Петербурге наблюдения за возведением и реализацией типовых проектов осуществлял А.В. Успенский, в Петергофе - В.В. Бочаров, в Твери И.И. Бондарев, в Пскове - Д.К. Костомаров, а в Варшавском военном округе - В. Юноша-Петровский.

В центральной части империи в начале прошлого века типовые воинские храмы появились в Туле, Воронеже, Москве, Твери, Пскове.

В 1905 году на добровольные пожертвования и отпущенные из казны 10000 рублей, в городе Туле был за один год отстроен и освящён храм Рождества Пресвятой Богородицы для 11-го пехотного Псковского генерал-фельдмаршала князя Смоленского М.И. Кутузова полка и 12-го Великолуцкого полка. Как уже ранее отмечалось, до появления подобных храмов военнослужащим приходилось отправлять свои духовные потребности в маловместительных приходских церквях, что создавало значительные неудобства. Так, в 1904 году при определении дислокации 12-го Великолуцкого полка в городе Тула было предложено военнослужащим посещать правый придел приходской Троицкой церкви, который мог вместить не более двухсот человек. На момент принятия решения о возведении стационарного храма свои походные церкви у этих полков уже существовали: у 11-го полка была походная церковь Рождества Богородицы, в которой проходили службы в походах Отечественной войны 1812 года, во время Турецкой (1877-1878), Русско-японскую (1904-1905) войн, а у 12-го Великолуцкого полка с 1811 года была походная церковь Святителя Николая, которая сопровождала подразделение при подавлении Польского мятежа и взятии Варшавы (1831), в Турецкую (1877-1878), Русско-японскую (1904-1905) войны. Можно только сожалеть, что и этот храм, имеющий прямое отношение к воинской славе, был снесён в 1925 году.

В качествеудачного примера можно привести реконструкцию, а по сути - полное воссоздание войсковой церкви Святителя

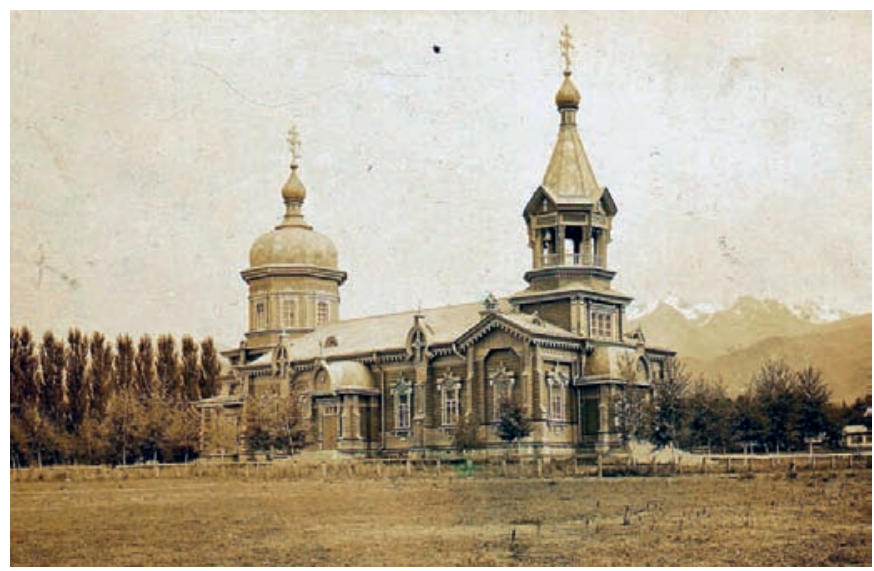

Рис. 28. Церковь Алексия митрополита Московского 20-го Туркестанского стрелкового полка. Алма-Ата, Казахстан (фото из открытых источников сети Интернет)

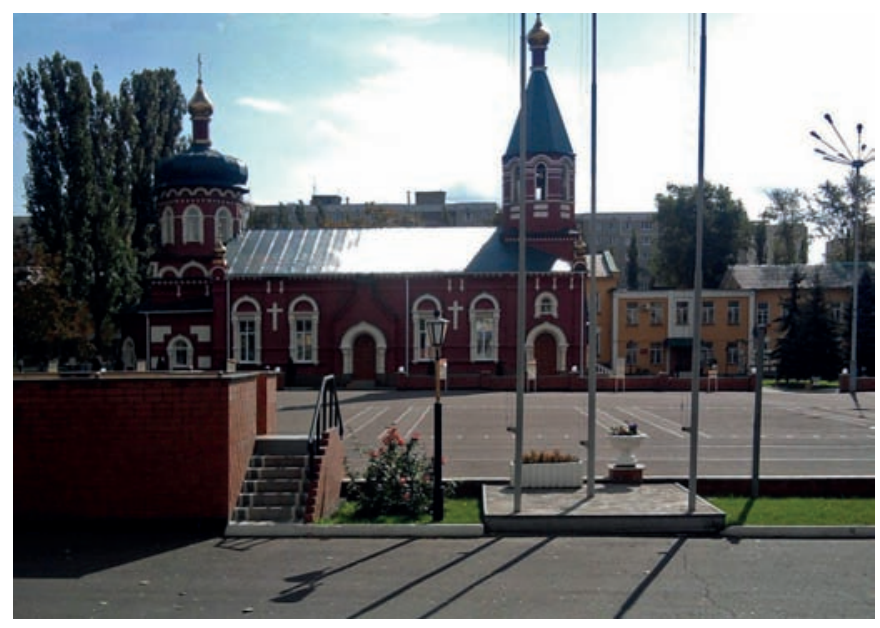

Рис. 29. Церковь Пантелеимона Целителя при Военно-воздушной академии имени профессора Н.Е. Жуковского и Ю.А. Гагарина. Воронеж. Фото А.И. Макарова

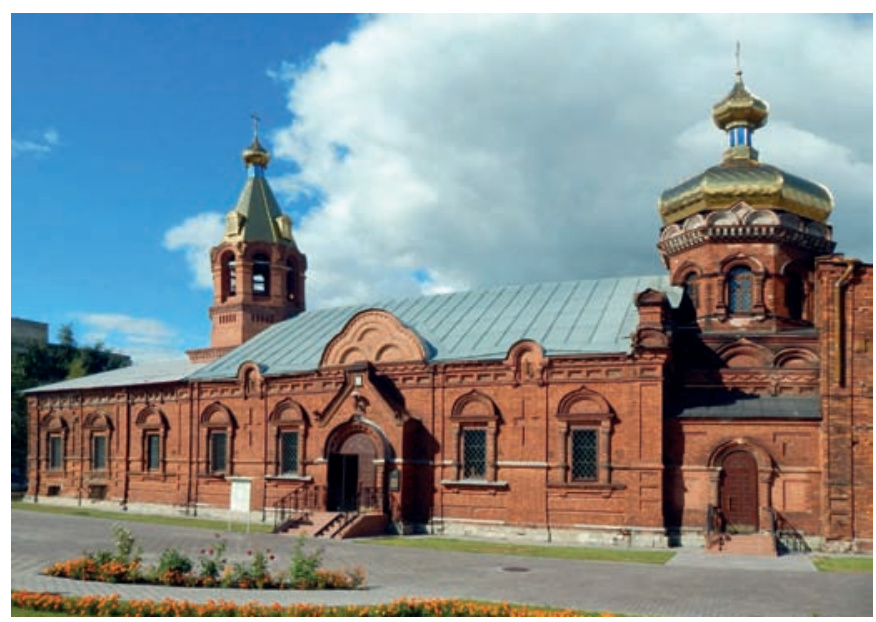

Рис. 30. Церковь во имя Владимирской иконы Божией Матери при бывшем 1-м лейб-драгунском Московском полку. Тверь. Фото А.И. Макарова 


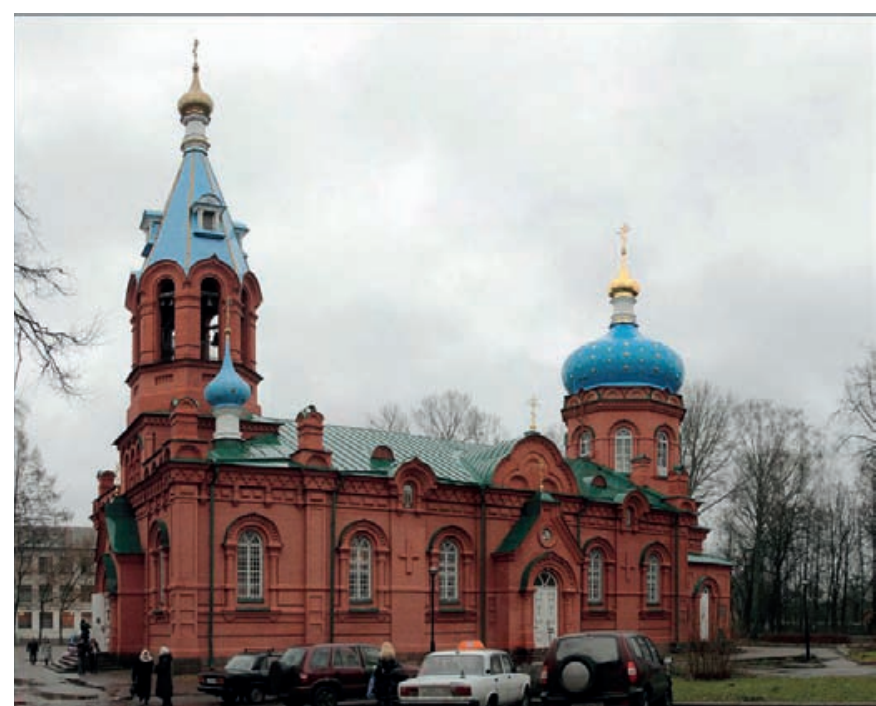

Рис. 31. Церковь Александра Невского при 76-й десантно-штурмовой дивизии. Псков (фото из открытых источников сети Интернет)

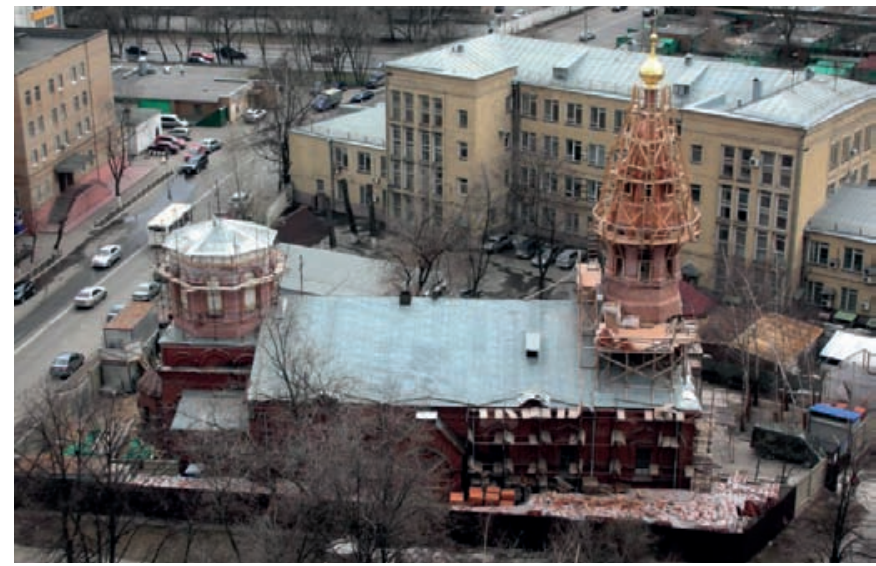

a)

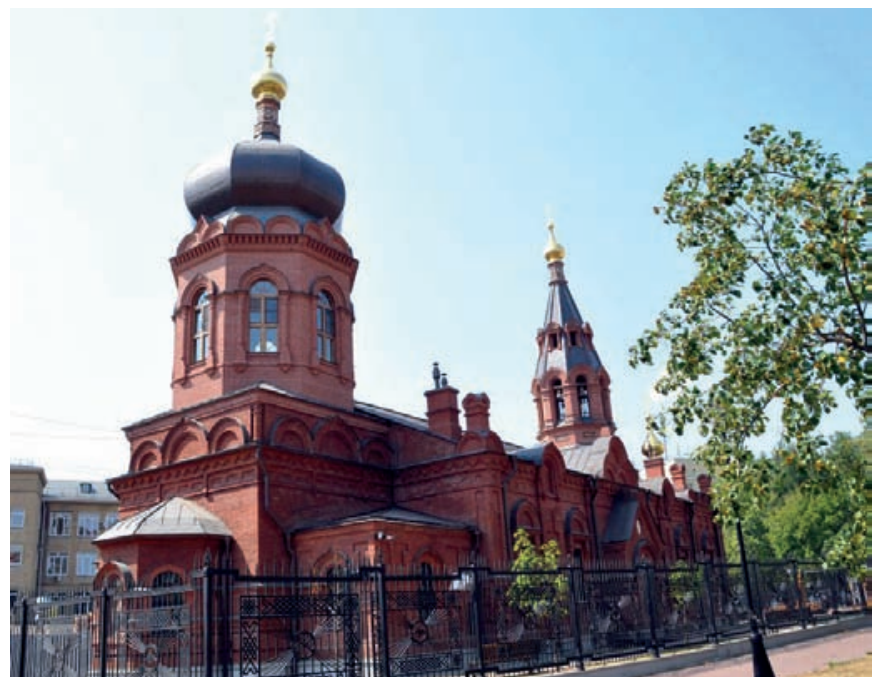

б)

Рис. 32. Церковь Благовещения Пресвятой Богородицы при штабе ВДВ в Сокольниках: а) в процессе восстановления; б) современное состояние. Москва, ул. Матросская Тишина, 9 (фото из открытых источников сети Интернет)
Пантелеймона, построенной в 1916 году при Воронежском дисциплинарном батальоне. Сейчас этот храм функционирует при Военно-воздушной академии имени Жуковского и Гагарина (рис. 29).

Как уже отмечалось, строительство типовых войсковых храмов проходило в короткие сроки. Например, 21 мая 1903 года в городе Твери состоялась закладка церкви во имя Владимирской иконы Божией Матери 1-го лейб-драгунского Московского полка, а 26 мая 1904 года этот храм, вмещавший до 900 человек, был освящён в присутствии командующего Московского военного округа великого князя Сергея Александровича (убит террористом И. Каляевым 4 февраля 1905 года). И, как уже вошло в практику, строительство типовых армейских церквей и детальную разработку проекта осуществил местный архитектор И.Е. Бондарев, и им же был создан и удачно реализован проект внутренней отделки. В качестве нововведения, применявшегося при постройке этого типа храма, было устроено калориферное отопление с подогревом воздуха. В 1936 году храм закрыли, шатровая колокольня была разобрана, купол был снесён, и ликвидирована алтарная апсида. Для клуба «Заря», который разместился в храме, было сооружено новое перекрытие. В настоящее время в воссозданном храме проходят богослужения (рис. 30).

Воинский храм во имя благоверного князя Александра Невского для расквартированного в городе Пскове 96-го Омского полка был отстроен в период двух строительных сезонов за 14 месяцев и освящён 4 октября 1908 года ${ }^{7}$ (рис. 31).

В 1920 году прошлого века, храм был передан «революционному красноармейскому театру», потом помещение занимал гарнизонный дом офицеров, а затем там разместился склад.

С марта 1992 года в храме возобновилась приходская жизнь, и постепенно псковские реставраторы при участии московских архитекторов А.И. Хамцова и Н.С. Василенко вернули ему первоначальный облик. Примечательно, что этот храм стал вновь воинским при 76 десантной штурмовой Псковской дивизии.

Весьма интересно, что в Москве в Сокольниках частично сохранился и был удачно восстановлен храм Благовещения Пресвятой Богородицы 6-ой сапёрной бригады Московского военного округа, казармы которой находились напротив храма. Заложен он был 6 сентября 1903 года также в присутствии генерал-губернатора Москвы великого князя Сергея Александрович. В строительстве храма принимали участие не только сапёры:

История этого полка весьма любопытна: он был сформирован в 1797 году, когда генерал-поручику князю М.И. Кутузову было поручено сформировать егерской полк, включив в него опытных боевых офицеров. Полк увенчался славой в Отечественной войне 1812 года, а название 0мского получил в 1863 году после его слияния с Копорским мушкетёрским полком, также доблестно сражавшимся в войне с Наполеоном. Надо отметить, что Омский полк являлся элитной частью русской армии, в силу чего за свои заслуги ежегодного приглашался на военные парады в Санкт-Петербург и нёс караульную службу в местах проживания августейших особ. 96-ой 0мский полк сражался за освобождение Болгарии от Османского ига (1877-1778), а в Первую мировую войну участвовал в серьёзных войсковых операциях на Западном фронте (источник: https://ru.wikipedia.org/wiki). 
живопись внутри храма была выполнена чинами 6-го полевого инженерного парка под руководством поручика Грюнфельда, трёхъярусный дубовый иконостас - воинами сапёрного полка, и ими же написаны иконы. Приветственную телеграмму на освящение храма прислал император Николай $\mathrm{II}^{8}$.

В конце 1915 года в помещении казарм сапёрного батальона (воинский контингент находился на фронте) был размещён эвакуированный из Варшавы Кадетский корпус генералиссимуса графа Суворова-Рымникского, воспитанники которого именовались «суворовцами». Всего в период Первой мировой войны во всех лечебных заведениях Сокольнического района было размещено более десяти военных госпиталей, и скончавшихся от ран воинов хоронили около Благовещенского храма. Так рядом возникло воинское кладбище, которое, как и Лефортовское госпитальное (рядом с павильоном метро Семёновская), и Братское воинское (у метро Сокол), было впоследствии уничтожено. На этом месте появился сквер, а храм лишился колокольни и центрального купола.

В 2004 году Патриархом Алексием II при Благовещенском храме было учреждено Патриаршее подворье при штабе Воздушно-десантных войск в Сокольниках. В состав подворья вошли и другие храмы, находящиеся на территории воинских частей Воздушно-десантных войск, расквартированных в Москве и Подмосковье. В соответствии с традицией возрождённой Российской армии на стенах установлены мемориальные доски с именами погибших воинов (рис. 32).

Таким образом, традиция продолжается.

\footnotetext{
8 Первым настоятелем храма был назначен священник Василий Слюнин который в качества пастора 5-го Сибирского полка во время войны с Японией (1904-1905) с первого и до последнего дня принимал участие в обороне Порт-Артура, где и получил контузию. Его боевые заслуги были отмечены 3 боевыми орденами: Святой Анны 3 степени с мечами, Святого Владимира с мечами, Святой Анны 2 степени с мечами и наперстным золотым крестом на Георгиевской ленте из Кабинета Его Императорского Величества. В данном случае хотелось бы отметить, что вышеперечисленные награды имели высокий статус. В московском храме о. Василий служил вплоть до 1915 года, а затем был переведён с повышением и назначен духовником лейб-гвардии Атаманского полка, квартировавшегося в Санкт-Петербурге и шефом которого являлся цесаревич Алексий. В Первую мировую войну о. Василий принимал непосредственное участие в боях на Германском фронте и, попав в плен, провёл в нем около трёх лет. Служил он в московском храме вплоть до его закрытия в 1923 году и скончался от эпидемии тифа.
}

\section{Лumepamypa}

1. Лапин, В.В. Военная столица Российской империи в фотографиях конца XIX - начала XX века : альбом / В.В. Лапин. - СПб : Лики России, 2008. - 240 с.; 275 фотогр.

2. Клавинг, В.В. Военные храмы России / В.В. Клавинг. СПб : Православный летописец, 2000. - 160 с.

3. Гусаров, А.Ю. Утраченные храмы Петербурга / А.Ю. Гусаров. - СПб : Паритет, 2014. - 368 с., ил.

4. Антонов, B.В. Утраченные памятники архитектуры Петербурга-Ленинграда : Каталог выставки / В.В. Антонов, А.В. Кобак. - Л. : Изокомбинат «Художник РСФСР», 1988. - 48 с.

5. Петербург-Петроград-Ленинград : Каталог фотооткрыток в 4 томах / Ред.-сост. В. П. Третьяков ; авт. текста Е. В. Анисимов // Из собрания ГМЗ «Петергоф». - СПб: Сад искусств, 2011-2013.

6. Антонов, В.В. Святыни Санкт-Петербурга. Энциклопедия христианских храмов / В.В. Антонов, А.В. Кобак. - СПб : Лики России, 2010. - 512 с.

7. Шульи, С. Храмы Санкт-Петербурга. История и современность / С. Шульц. -СПб : Глаголь, 1994. - 320 с.

\section{References}

1. Lapin V.V. Voennaya stolitsa Rossiiskoi imperii v fotografiyakh kontsa XIX - nachala KhKh veka : al'bom [The military capital of the Russian Empire in photographs of the late XIX - early XX century: album]. St. Petersburg, Liki Rossii Publ., 2008, 240 p.; 275 photos.

2. Klaving V.V. Voennye khramy Rossii [Military churches of Russia]. St. Petersburg, Pravoslavnyi letopisets Publ., 2000, 160 p.

3. Gusarov A.Yu. Utrachennye khramy Peterburga [Lost temples of St. Petersburg]. St. Petersburg, Paritet Publ., 2014, 368 p., il.

4. Antonov V.V., Kobak A.V. Utrachennye pamyatniki arkhitektury Peterburga-Leningrada : Katalog vystavki [Lost architectural monuments of St. Petersburg - Leningrad: Exhibition catalog]. Leningrad, Izokombinat "Khudozhnik RSFSR" Publ., 1988, 48 p.

5. Peterburg-Petrograd-Leningrad: Katalog fotootkrytok v 4 tomakh [Petersburg - Petrograd - Leningrad: Catalog of photo cards in 4 volumes]. sost. V.P. Tret'yakov (ed.); authortextofE.V. Anisimov/From the collection ofGMZ “Peterhof”. St. Petersburg, Garden of Arts Publ., 2011-2013.

6. Antonov V.V., Kobak A.V. Svyatyni Sankt-Peterburga. Entsiklopediya khristianskikh khramov [Shrines of St. Petersburg. Encyclopedia of Christian Temples]. St. Petersburg, Liki Rossii Publ., 2010, 512 p.

7. Shul'ts, S. Khramy Sankt-Peterburga. Istoriya i sovremennost' [Temples of St. Petersburg. History and Modernity]. St. Petersburg, Glagol Publ., 1994, 320 p.

Макаров Александр Игоревич (Москва). Кандидат юридических наук. Профессор кафедр «Храмовое зодчество» и «Архитектура сельских населённых мест» Московского архитектурного института (государственной академии) (107031, Москва, ул. Рождественка, 11/4. МАРХИ). E-mail: arch_sacra@marhi.ru.

Makarov Alexander I. (Moscow). Candidate of Legal Sciences. Professor of the Departments "Temple Architecture" and "Architecture of rural populated areas" of the Moscow Architectural Institute (MArchI State Academy) (11/4 Rozhdestvenka st, Moscow, 107031. MArchI).E-mail: arch_sacra@marhi.ru. 